\title{
The Emerging Role of Exosomes in Diagnosis, Prognosis, and Therapy in Head and Neck Cancer
}

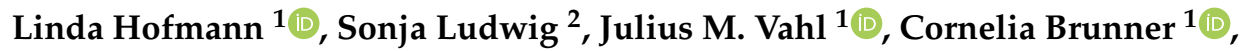 \\ Thomas K. Hoffmann ${ }^{1}$ and Marie-Nicole Theodoraki ${ }^{1, *}$ \\ 1 Department of Otorhinolaryngology, Head and Neck Surgery, Ulm University Medical Center, \\ 89075 Ulm, Germany; linda.hofmann@uni-ulm.de (L.H.); Julius.Vahl@uniklinik-ulm.de (J.M.V.); \\ cornelia.brunner@uniklinik-ulm.de (C.B.); t.hoffmann@uniklinik-ulm.de (T.K.H.) \\ 2 Department of Otorhinolaryngology, Head and Neck Surgery, University Hospital Mannheim, \\ 68167 Mannheim, Germany; sonja.ludwig@umm.de \\ * Correspondence: marie-nicole.theodoraki@uniklinik-ulm.de
}

Received: 17 May 2020; Accepted: 4 June 2020; Published: 6 June 2020

\begin{abstract}
Exosomes, the smallest group of extracellular vesicles, carry proteins, miRNA, mRNA, DNA, and lipids, which they efficiently deliver to recipient cells, generating a communication network. Exosomes strongly contribute to the immune suppressive tumor microenvironment of head and neck squamous cell carcinomas (HNSCC). Isolation of exosomes from HNSCC cell culture or patient's plasma allows for analyzing their molecular cargo and functional role in immune suppression and tumor progression. Immune affinity-based separation of different exosome subsets, such as tumor-derived or T cell-derived exosomes, from patient's plasma simultaneously informs about tumor status and immune dysfunction. In this review, we discuss the recent understanding of how exosomes behave in the HNSCC tumor microenvironment and why they are promising liquid biomarkers for diagnosis, prognosis, and therapy in HNSCC.
\end{abstract}

Keywords: exosomes; HNSCC; liquid biomarker; tumor microenvironment

\section{Introduction}

Head and neck squamous cell carcinomas (HNSCC) account for the sixth most common cancer worldwide and are characterized by profound immune suppression. Dysregulated cytokine profiles, impaired activity of effector immune cells, and elevated levels of regulatory immune cells contribute to a highly immune suppressive tumor microenvironment (TME) [1-3]. Advanced and recurrent HNSCC have limited therapeutic options, and disease outcome remains poor. Immune therapies aiming to restore patient's antitumor immune response emerged as promising treatment options for HNSCC $[1,3,4]$. Antibodies blocking immune checkpoint molecules PD-1 (e.g., pembrolizumab and nivolumab) or CTLA-4 (e.g., ipilimumab) aim to reactivate cytotoxic T lymphocytes $[5,6]$ and are focus of current clinical trials. Yet, only a fraction of patients with recurrent/metastatic and platin-refractory disease $[7,8]$ or platin naïve disease [9] who were treated with PD-1 antibodies showed prolonged remission and improved survival [10].

Among the mediators contributing to immune suppression in HNSCC, exosomes have become of special interest. Exosomes, the smallest $(30-150 \mathrm{~nm}$ ) of the extracellular vesicles (EVs), are released by all cell types and mediate intercellular communication [11]. Exosomes differ from other EVs by their origin-unique cargo, as their biogenesis process in the endosomal compartment allows them to recapitulate the molecular characteristics of the parental cell [12]. Microvesicles are formed by simple budding of the plasma membrane, whereas exosomes are released upon fusion of the plasma membrane with multivesicular bodies (MVB), which are formed after inward budding of the endosomal 
membrane (Figure 1) [13]. The molecular cargo of exosomes consists of proteins, miRNA, mRNA, DNA, and lipids [14] and is effectively delivered to recipient cells, generating a communication network. Tumors, including HNSCC, are avid exosome producers and plasma of HNSCC patients is enriched in exosomes [15]. As part of the communication network between tumor cells and immune cells within the TME, exosomes play a major role in immune suppression and the regulation of tumor progression [16-18]. Due to their unique biogenesis, their ability to circulate freely in body fluids and their manifold molecular cargo, exosomes have emerged as promising noninvasive liquid biomarkers $[19,20]$. Several studies showed recently that exosomes have great potential as liquid biomarkers in HNSCC not only for disease activity and tumor stage but also for level of immune suppression and therapy response and outcome [21-24].

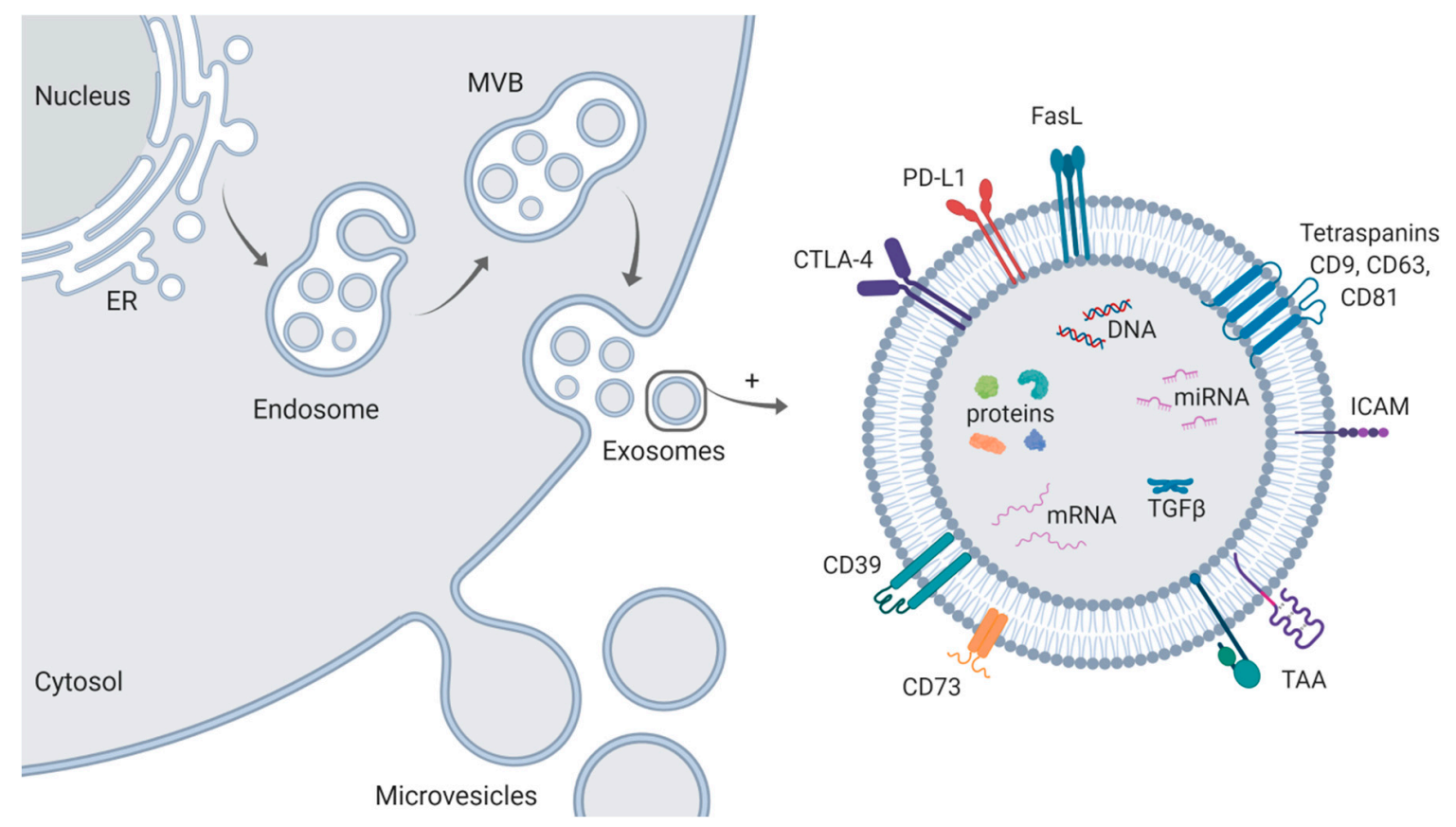

Figure 1. Schematic representation of exosome biogenesis and molecular cargo. Exosomes are formed through inward budding of the endosomal membrane resulting in the formation of multivesicular bodies (MVB). Upon fusion of MVBs with the plasma membrane, exosomes are released in the extracellular space. In contrast, microvesicles are formed by simple budding of the plasma membrane. The molecular cargo of exosomes consists of proteins, miRNA, mRNA, DNA, and lipids. On their surface, they carry the tetraspanins CD9, CD63, and CD81, commonly referred to as "exosomal markers," adhesion molecules (e.g., intercellular adhesion molecule ICAM) and-in case of TEX-tumor-associated antigens (TAA), which are specific to the cell of origin. Further, the presence of immune suppressive proteins such as CTLA-4, PD-L1, Fas-L, CD39, CD73, and TGF $\beta$ in HNSCC-derived exosomes has been reported. Figure is created with BioRender.

\section{Isolation and Characterization of Exosomes}

Biomarker studies and clinical monitoring with high sample numbers require a fast, high-throughput applicable method for isolation of pure and abundant exosomes. Commonly used methods such as ultracentrifugation, density-gradient centrifugation, or precipitation $[25,26]$ do not fully meet these requirements. Mini-size exclusion chromatography (mini-SEC) has been established and standardized for this purpose (Figure 2) [27]. It enables reproducible isolation of unaggregated exosomes from plasma, which were morphologically and biologically intact as examined in functional coincubation assays with immune cells [27]. To estimate the quality and purity of exosome preparations and to ensure reliability and comparability of studies performed by different 
investigators, the 2018 minimal information for studies of extracellular vesicles (MISEV) guidelines provide criteria for the definition of EVs and recommendations regarding experimental setups and data interpretation [28]. Accordingly, exosomes need to be characterized for morphology and shape by transmission electron microscopy, size by nanoparticle tracking, and the presence of endosomal markers (such as TSG101) and tetraspanins (CD9, CD63, and CD81) by Western blot [28].

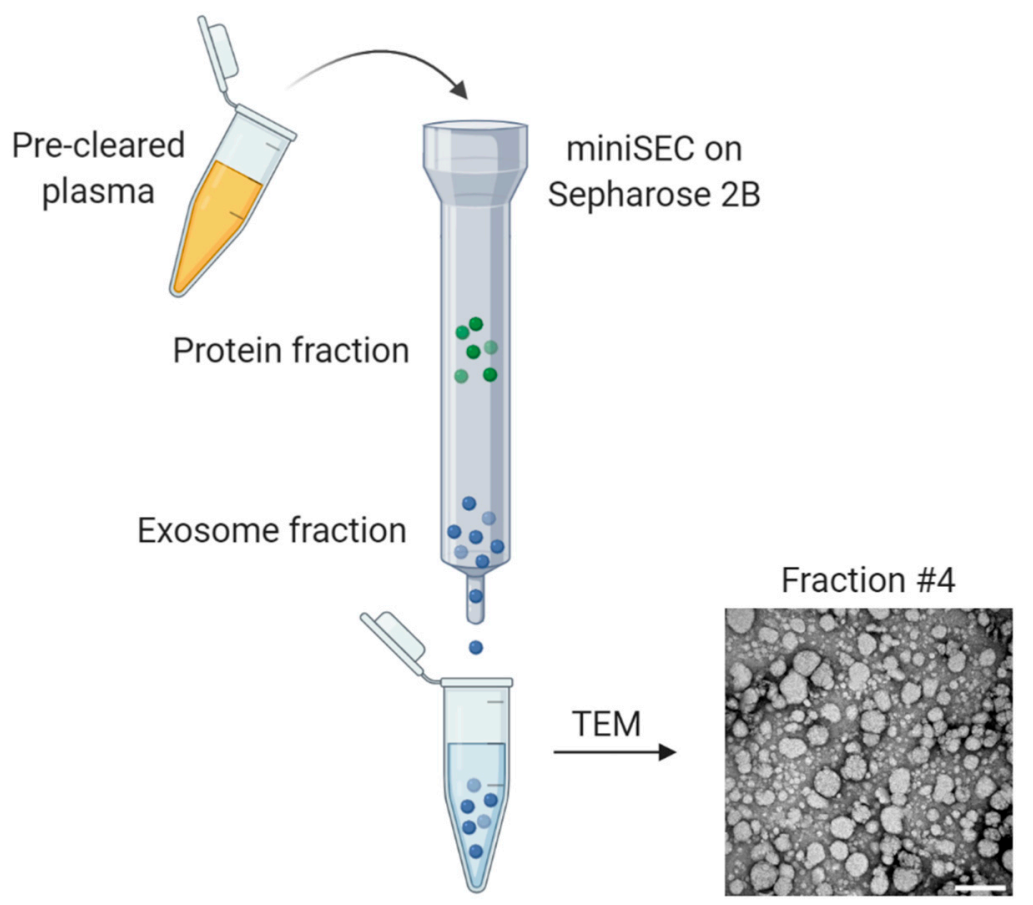

Figure 2. Schematic representation of exosome isolation from plasma using mini-size exclusion chromatography (mini-SEC). Precleared plasma is applied onto a Sepharose 2B column and eluted by serially applying $1 \mathrm{~mL}$ PBS. Fraction \#4 is enriched in morphologically intact, nonaggregated exosomes as shown in the representative transmission electron microscopy (TEM) picture. Scalebar $=200 \mathrm{~nm}$. Figure is created with BioRender.

To examine the role of exosomes in HNSCC immune suppression and their potential as liquid biomarkers, the molecular content of exosomes isolated from both cell culture supernatants and plasma has been analyzed by different techniques, and results are presented in the following sections.

\section{Exosomes Mediate Immune Suppression and Tumor Progression in HNSCC}

Although plasma-derived exosomes are a mixture of exosomes derived from different cell types, exosomes from supernatants of tumor cell lines are exclusively tumor-derived (TEX) with no other exosomes present. Thus, the TEX molecular cargo represents a small copy of the parental tumor cell [29]. Much of the current knowledge about the influence of exosomes on the TME was gained by analyzing TEX derived from supernatants of human tumor cell lines (Table 1). Culture conditions of several HNSCC cell lines have been optimized for use with mini-SEC to yield best TEX purity and recovery [30]. Various studies showed that TEX carry immune suppressive proteins and alter the function of recipient immune cells resulting in immune dysfunction [31-33]. Even more, TEX were shown to reduce proliferation of CD8+ T cells and induce their apoptosis [31,33]. Simultaneously, TEX promoted expansion, suppressive activity, and resistance of apoptosis of regulatory $\mathrm{T}$ cells (Treg) $[31,34,35]$. TEX-mediated changes on T lymphocytes are described both on transcriptional and functional levels. After incubation with TEX, T cells showed remarkable changes in mRNA expression of various immune response-related genes. These changes translated into reduced CD69 expression on activated $\mathrm{T}$ cells and increased production of immune-suppressive adenosine by Treg [32]. 
Further, TEX were shown to induce tumor innervation [36] and angiogenesis through reprogramming of endothelial cells within the TME [37]. Migration and invasion were induced in a poorly metastatic oral cancer cell line when coincubated with TEX derived from a highly metastatic cell line [38]. Oral squamous cell carcinoma (OSCC)-derived exosomes carrying EGFR transformed normal epithelial cells into a mesenchymal phenotype, and the anti-EGFR therapeutic antibody cetuximab inhibited this carcinogenic effect of TEX [39]. In response to TEX, oral keratinocytes revealed a modulated transcriptome profile that contributed to cancer-associated pathologies such as angiogenesis, immune evasion, and metastasis [40]. Another involvement of TEX has been found in the context of hypoxia, a key factor driving cancer progression and metastasis [41]. As such, TEX derived from hypoxic OSCC cells promoted migration and invasion of normoxic OSCC cells by delivery of miR-21 [42].

Overall, these observations emphasize that TEX-mediated modulation of the TME contributes to immune suppression, tumor growth, and metastasis in HNSCC.

So far, in vivo studies on the effect of systemically delivered TEX on HNSCC tumor progression or immune suppression are rare (Table 2). Early studies with xenograft tumor models showed that OSCC cell-derived exosomes promoted tumor growth in vivo [43]. Further, TEX derived from hypoxic tumor cells induced tumor growth and metastasis in a xenograft model of OSCC [42]. More recently, a 4-nitroquinoline 1-oxide (4NQO) carcinogen-induced orthotopic model of OSCC in C57BL/6 mice was employed $[37,44]$. The tumorigenic compound $4 \mathrm{NQO}$ causes intracellular oxidative stress followed by mutations and DNA strand breaks [45]. The oral mucosa finally undergoes a malignant transformation process that mimics human oral cavity neoplastic transformation in vivo [46,47]. Intravenous TEX administration to $4 \mathrm{NQO}$-conditioned mice at a premalignant stage facilitated disease progression from a premalignant epithelial to a malignant mesenchymal phenotype and reduced the number of tumor-infiltrating lymphocytes [44]. Further, TEX administration resulted in increased vascularization within the tumor and thus promoted angiogenesis in 4NQO-conditioned mice [37].

These findings confirm the pathophysiological role of TEX in HNSCC tumorigenesis and disease progression in vivo and are summarized in Table 2. In addition, the 4NQO model represents a suitable tool for further investigation of TEX-driven carcinogenesis in vivo. 
Table 1. Effects of exosomes on the tumor microenvironment: in vitro studies.

\begin{tabular}{|c|c|c|c|}
\hline Exosome Source & Isolation Method & Outcome & Reference \\
\hline PCI-13 HNSCC cell line & $\begin{array}{l}\text { Differential centrifugation and } \\
\text { mini-SEC }\end{array}$ & $\begin{array}{c}\text { TEX induced apoptosis of activated CD8+ T cells and modulated Treg } \\
\text { suppressor functions via cell surface signaling. }\end{array}$ & [33] \\
\hline PCI-13 HNSCC cell line & SEC and ultracentrifugation & $\begin{array}{l}\text { TEX inhibited signaling and proliferation of activated CD8+ T cells and } \\
\text { induced expansion of Treg. }\end{array}$ & [31] \\
\hline PCI-13 HNSCC cell line & SEC and ultracentrifugation & $\begin{array}{c}\text { TEX induced generation, expansion, biologic activity, and resistance to } \\
\text { apoptosis of Treg. }\end{array}$ & [35] \\
\hline $\begin{array}{l}\text { C15 and C17 PDX (patient-derived } \\
\text { xenograft) NPC cell line }\end{array}$ & $\begin{array}{l}\text { Differential centrifugation and } \\
\text { sucrose gradient flotation }\end{array}$ & TEX facilitated Treg recruitment and expansion of CD25 high FOXP3 ${ }^{\text {high }}$ Treg. & [34] \\
\hline PCI-13 HNSCC cell line & $\begin{array}{l}\text { Differential centrifugation, SEC, } \\
\text { and ultracentrifugation }\end{array}$ & $\begin{array}{l}\text { TEX regulated expression of immune-function related genes in T cell subsets } \\
\text { translating into increased adenosine production and loss of CD69 expression } \\
\text { on activated T cells. }\end{array}$ & [32] \\
\hline $\begin{array}{l}\text { UM-SCC-1, UM-SCC-19, UM-SCC-47, } \\
\text { and 96-VU-147T-UP-6 HNSCC cell lines }\end{array}$ & $\begin{array}{l}\text { Differential ultracentrifugation and } \\
\text { iodixanol gradient centrifugation }\end{array}$ & $\begin{array}{l}\text { TEX and exosomes from patients (both plasma and tumor) stimulated } \\
\text { neurite outgrowth in PC12 neuronal model cells. }\end{array}$ & [36] \\
\hline PCI-13 and UM-SCC47 HNSCC cell lines & $\begin{array}{c}\text { Differential centrifugation and } \\
\text { mini-SEC }\end{array}$ & $\begin{array}{l}\text { TEX stimulated proliferation, migration, and tube formation of endothelial } \\
\text { cells, thus promoting angiogenesis. }\end{array}$ & [37] \\
\hline HOC313 OSCC cell line & SEC and ultracentrifugation & $\begin{array}{l}\text { TEX from highly metastatic cells induced cell growth and promoted cell } \\
\text { motility of poorly metastatic cells through the delivery of miR-1246. }\end{array}$ & [38] \\
\hline HSC-3 and RT-7 OSCC cell lines & $\begin{array}{l}\text { Differential centrifugation and } \\
\text { Total Exosome Isolation Kit } \\
\text { (Invitrogen) }\end{array}$ & $\begin{array}{l}\text { EGFR-positive TEX transformed normal epithelial cells into a mesenchymal } \\
\text { phenotype which was inhibited by cetuximab. }\end{array}$ & [39] \\
\hline $\begin{array}{l}\text { Ca1, CaLH2, SQCC/Y1, SVpgC2a, and } \\
\text { SVFN8 OSCC cell lines }\end{array}$ & $\begin{array}{l}\text { Differential centrifugation and } \\
\text { ultracentrifugation }\end{array}$ & $\begin{array}{l}\text { TEX changed transcriptome profile in oral keratinocytes regarding pathways } \\
\text { involved in matrix remodeling and immune modulation. }\end{array}$ & [40] \\
\hline SCC-9 and CAL-27 OSCC cell lines & $\begin{array}{l}\text { ExoQuick Exosome Precipitation } \\
\text { Kit (System Biosciences) }\end{array}$ & $\begin{array}{l}\text { TEX derived from hypoxic cells increased migration and invasion of } \\
\text { normoxic cells by delivery of miR-21. }\end{array}$ & [42] \\
\hline $\begin{array}{l}\text { HPV(+) UM-SCC-2, UM-SCC-47, } \\
\text { UPCI-SCC-90, HPV(-) PCI-13, and } \\
\text { PCI-30 HNSCC cell lines }\end{array}$ & $\begin{array}{l}\text { Differential centrifugation and } \\
\text { mini-SEC }\end{array}$ & $\begin{array}{c}\mathrm{HPV}(+) \text { and HPV(-) TEX carried immune modulatory proteins and } \\
\text { inhibited T cell function. Only HPV(-) TEX suppressed dendritic cell } \\
\text { function. }\end{array}$ & [48] \\
\hline $\begin{array}{l}\text { HPV(+) UM-SCC-2, UM-SCC-47, } \\
\text { UPCI-SCC-90, HPV(-) PCI-13, and } \\
\text { PCI-30 HNSCC cell lines }\end{array}$ & $\begin{array}{l}\text { Differential centrifugation and } \\
\text { mini-SEC }\end{array}$ & $\begin{array}{l}\text { The proteomic cargo differed between } \mathrm{HPV}(+) \text { and } \mathrm{HPV}(-) \text { TEX. HPV(+) } \\
\text { TEX were enriched in CD47 and CD276, whereas HPV(-) TEX contained } \\
\text { tumor-protective/growth-promoting antigens, MUC-1 and HLA-DA. }\end{array}$ & [49] \\
\hline $\begin{array}{l}\text { HPV(+) SCC-90, SCC-47, SCC-104, } \\
\text { HPV(-) SAS, CAL-27, and CAL-33 } \\
\text { HNSCC cell lines }\end{array}$ & $\begin{array}{l}\text { Differential centrifugation and } \\
\text { ultracentrifugation }\end{array}$ & $\begin{array}{l}\text { MiR-9-enriched TEX from HPV(+) HNSCC transformed macrophages into } \\
\text { the M1 phenotype and increased the radiosensitivity of HPV(+) HNSCC. }\end{array}$ & [50] \\
\hline
\end{tabular}


Table 1. Cont

\begin{tabular}{|c|c|c|c|c|c|c|}
\hline \multicolumn{2}{|l|}{ Exosome Source } & \multicolumn{2}{|c|}{ Isolation Method } & \multicolumn{2}{|r|}{ Outcome } & Reference \\
\hline \multicolumn{2}{|c|}{ HSC-3 and SCC-9 OSCC cell lines } & \multicolumn{2}{|c|}{$\begin{array}{l}\text { Differential centrifugation and } \\
\text { ultracentrifugation }\end{array}$} & \multicolumn{2}{|c|}{$\begin{array}{l}\text { TEX derived from cisplatin-resistant cells induced chemoresistance in } \\
\text { platin-naive cells and decreased DNA damage signaling in response to } \\
\text { cisplatin. }\end{array}$} & [51] \\
\hline \multicolumn{2}{|c|}{$\begin{array}{l}\text { Primary, HNSCC patient-derived } \\
\text { cancer-associated fibroblasts }\end{array}$} & \multicolumn{2}{|c|}{$\begin{array}{l}\text { Differential centrifugation and } \\
\text { ultracentrifugation }\end{array}$} & \multicolumn{2}{|c|}{$\begin{array}{l}\text { TEX derived from cisplatin-resistant cancer-associated fibroblasts conferred } \\
\text { chemoresistance and an aggressive phenotype in cancer cells by transfer of } \\
\text { functional miR-196a. }\end{array}$} & [52] \\
\hline \multicolumn{2}{|c|}{$\begin{array}{l}\text { KYSE30, KYSE70, and KYSE180 ESCC } \\
\text { cell lines }\end{array}$} & \multicolumn{2}{|c|}{$\begin{array}{l}\text { Differential centrifugation and } \\
\text { ultracentrifugation }\end{array}$} & \multicolumn{2}{|c|}{$\begin{array}{c}\text { Radioresistant cells showed a differential miRNA expression profile } \\
\text { compared to normal cells and exosomal miR-339-5p mediated regulation of } \\
\text { radiosensitivity. }\end{array}$} & [53] \\
\hline UM-SCC-6 HNSCC cell lin & & \multicolumn{2}{|c|}{ Differential centrifugation and SEC } & \multicolumn{2}{|c|}{$\begin{array}{c}\text { Proteomic analysis of TEX released from irradiated cells revealed } \\
\text { overexpressed proteins involved in response to radiation, ROS metabolism, } \\
\text { and DNA repair. }\end{array}$} & [54] \\
\hline FaDu HNSCC cell line & & \multicolumn{2}{|c|}{$\begin{array}{l}\text { Total Exosome Isolation Kit } \\
\text { (Invitrogen) and ultracentrifugation }\end{array}$} & \multicolumn{2}{|c|}{$\begin{array}{l}\text { Proteomic profile of TEX released from irradiated cells was significantly } \\
\text { altered compared to TEX from nonirradiated cells. }\end{array}$} & [55] \\
\hline BHY and FaDu HNSCC cell 1 & & \multicolumn{2}{|c|}{$\begin{array}{l}\text { Differential centrifugation and } \\
\text { ultracentrifugation }\end{array}$} & \multicolumn{2}{|c|}{$\begin{array}{l}\text { TEX derived from irradiated cells promoted survival and proliferation and } \\
\text { conferred a migratory phenotype to recipient cancer cells. }\end{array}$} & {$[56,57]$} \\
\hline Exosome Source & & Isolation Method & & Mouse Model & Outcome & Reference \\
\hline OSC-4 OSCC cell line & & $\begin{array}{l}\text { Exosome Isolation Kit } \\
\text { (Invitrogen) }\end{array}$ & $\begin{array}{r}\text { OSC }-4 x \\
\text { in }\end{array}$ & $\begin{array}{l}\text { enografts implanted } \\
\text { tho nude mice }\end{array}$ & $\begin{array}{l}\text { TEX promoted growth rate of tumor xenografts, } \\
\text { which could be inhibited by continuous } \\
\text { administration of heparin. }\end{array}$ & [43] \\
\hline $\begin{array}{l}\text { SCC-9 and CAL-27 OSCC cell } \\
\text { lines }\end{array}$ & & $\begin{array}{l}\text { ExoQuick Exosome } \\
\text { ecipitation Kit (System } \\
\text { Biosciences) }\end{array}$ & $\begin{array}{r}\text { CAL-27 } \\
\text { ir }\end{array}$ & $\begin{array}{l}\text { xenografts implanted } \\
\text { tto nude mice }\end{array}$ & $\begin{array}{l}\text { Tumor-derived exosomal miR-21 induced tumor } \\
\text { growth and metastasis in a xenograft OSCC model. }\end{array}$ & [42] \\
\hline $\begin{array}{l}\text { PCI-13 and UM-SCC-47 } \\
\text { HNSCC cell lines }\end{array}$ & Diffe & $\begin{array}{l}\text { rential centrifugation and } \\
\text { mini-SEC }\end{array}$ & $4-\mathrm{NQO}$ & $\begin{array}{l}\text { oral carcinogenesis } \\
\text { nouse model }\end{array}$ & $\begin{array}{l}\text { TEX promoted formation of defined vascular } \\
\text { structures within the tumor and thus, promoted } \\
\text { angiogenesis. }\end{array}$ & [37] \\
\hline $\begin{array}{l}\text { SCCVII, SCC-90, and PCI-13 } \\
\text { HNSCC cell lines }\end{array}$ & Diffe & $\begin{array}{l}\text { rential centrifugation and } \\
\text { mini-SEC }\end{array}$ & 4-NQO & $\begin{array}{l}\text { oral carcinogenesis } \\
\text { nouse model }\end{array}$ & $\begin{array}{l}\text { TEX promoted tumor progression and reduced } \\
\text { immune cell migration to the tumor. }\end{array}$ & [44] \\
\hline
\end{tabular}




\section{Molecular and Functional Profiles of Exosomes from HPV(+) and HPV(-) Tumors}

Infection with human papillomavirus (HPV) belongs to the main etiologic risk factors for HNSCC, especially in the oropharynx with an HPV prevalence of around 25\% [58-60]. Clinical, histopathological and molecular characteristics are different between HPV(+) and HPV(-) HNSCC [61]. $\mathrm{HPV}(+)$ tumors are generally more responsive to therapy and have a better prognosis and outcome with an approximately $60 \%$ reduced risk of death compared to HPV(-) tumors [62-64]. TEX from HPV(+) and HPV(-) HNSCC cell lines were analyzed regarding their differential capabilities to modulate the antitumor immune response $[48,49]$. Both HPV(+) and HPV $(-)$ TEX carried immunomodulatory molecules. However, only HPV(+) TEX promoted immune activity of dendritic cells by driving their maturation and the expression of antigen-processing machinery components on their surface [48]. Additionally, comparison of proteome profiles by mass spectrometry revealed differential content of protein cargos in HPV(+) and HPV(-) TEX [49]. The presence of CD47, a supposed antiphagocytic molecule, on HPV(+) TEX might support prolonged interactions with immune cells [49]. Recently, $\mathrm{HPV}(+) \mathrm{TEX}$ were found to foster M1 polarization of macrophages via miR-9, which may contribute to radiosensitivity of HNSCC [50].

Overall, HPV(+) and HPV(-) TEX are supposed to differentially modulate antitumor immune response thereby playing a role in disease progression and outcome. Hence, HPV(+) TEX might promote antitumor immune response thereby improving outcome of patients with $\mathrm{HPV}(+)$ cancers.

\section{Exosomes as Biomarkers for Disease Progression and Activity}

Studies with exosomes isolated from plasma of HNSCC patients are a prerequisite to establish their role as liquid biomarkers. HNSCC patients were shown to have significantly higher exosome levels compared to healthy donors $[15,27]$. Further, the exosomal protein concentration and molecular content are correlated with disease activity and tumor stage. Patients with active disease (AD) or Union for International Cancer Control (UICC) high stage had significantly higher exosome levels and higher levels of immune-suppressive molecules carried by these exosomes compared to patients with nonevident disease (NED) or UICC low stage [15,21]. Consistent with the immune modulatory characteristics of cell line-derived TEX, plasma-derived exosomes were shown to interfere with immune cells as they suppressed activation and proliferation of T lymphocytes [27]. Even more, exosomes derived from patients with AD were significantly more effective in inducing apoptosis of CD8+ T cells, suppression of CD4+ T cell proliferation, and induction of Treg activity than exosomes from patients with NED, thereby mediating stronger immune suppression [15]. Overall, plasma-derived total exosomes can distinguish between healthy donors and HNSCC patients as well as between low- and high-stage HNSCC.

The PD-1/PD-L1 pathway is an important immune suppressive mechanism operating in the TME and presenting a promising drug target for antibody-based immune therapies in HNSCC [1,3,4]. Yet, resistance to PD-1 blockade therapy is frequent. Exosomes derived from plasma of HNSCC patients were found to carry biologically active PD-L1, which suppressed function of activated T cells [21]. Relative levels of PD-L1 on exosomes were associated with disease activity, clinical stage, and the presence of lymph node metastasis. Patients whose exosomes showed high levels of PD-L1 had active or advanced disease. Further, exosomes with high levels of PD-L1 strongly suppressed T cell activity, whereas exosomes with low PD-L1 levels did not [21]. This immune-suppressive effect was almost completely reversed by adding an anti-PD-1 antibody to the $\mathrm{T}$ cell cultures prior to incubation with exosomes. In contrast to exosomal PD-L1, soluble PD-L1 levels did not correlate with clinicopathological data [21]. These findings can be explained by increased protein degradation of the unprotected soluble PD-L1 in contrast to stable PD-L1 integrated in the exosomal membrane. Thus, PD-L1 on exosomes emerged as a promising biomarker for disease progression of HNSCC. Similar correlations of exosomal PD-L1 with immune suppression and tumor growth have been later reported for other tumor entities, such as melanoma or lung cancer [65-67]. In future, the influence of PD-L1-positive exosomes on immune therapy and resistance needs to be evaluated. 
Exosomal miRNAs are supposed to have significant functions in the regulation of cancer progression [68]. miR-21 has been identified as a common proto-oncogene and its target genes are involved in several processes controlling carcinogenesis, such as proliferation, apoptosis, and invasion [69]. Patients with OSCC were found to have significantly higher levels of serum exosomal miR-21 compared to healthy volunteers [42]. Further, exosomal miR-21 levels correlated with $T$ stage and lymph node metastasis as well as with the tumor HIF- $1 \alpha / 2 \alpha$ expression, reflecting the hypoxic status of the tumor [42]. Similar studies revealed that miR-21 in serum-derived exosomes correlated with advanced tumor stage and metastasis in laryngeal (LSCC) [70] and esophageal squamous cell carcinoma (ESCC) [71]. These studies emphasized the clinical impact of exosomal miR-21 as a valuable biomarker for HNSCC progression.

Recently, a quantitative proteomics approach was applied to identify the protein content of serum-derived exosomes in OSCC patients with or without evidence of lymph node metastasis and compared to healthy controls [72]. Thereby, PF4V1, CXCL7, F13A1, and ApoA1, proteins involved in regulation of metastasis and cancer progression, were found to be differentially expressed and correlated to tumor differentiation level and metastasis. Receiver operating characteristic (ROC) curve analysis indicated that a combination of different biomarkers improved diagnostic accuracy compared to a single biomarker [72].

\section{TEX and Non-TEX as Biomarkers for Tumor Status and Immune Dysfunction}

Capture techniques based on immune affinity allow for the separation of exosomes according to their origin or presence of tumor-specific epitopes on their surface. This way, distinct exosome subsets can be analyzed regarding their potential as biomarkers. Using antibodies against chondroitin sulfate proteoglycan 4 (CSPG4), a tumor antigen selectively expressed by melanoma and other malignant but not normal cells [73,74], melanoma-derived TEX were successfully isolated from patients' plasma [75]. However, the molecular heterogeneity of HNSCC makes it difficult to identify markers for this tumor entity. A mix of antibodies recognizing antigens commonly overexpressed on HNSCC (EGFR, MAGEA3, EpCAM, and CSPG4) has been used for the construction of a microarray for TEX capture from plasma [22]. More recently, CD44v3 was evaluated as a tumor-associated protein to selectively enrich TEX from plasma of HNSCC [76]. CD44v3 overexpression has been linked to tumor progression and metastatic potential in HNSCC [77-79]. The molecular profile of CD44v3(+) TEX was strongly immune suppressive and correlated with higher disease stage and lymph node metastasis. Thus, CD44v3(+) TEX represented a potential biomarker of HNSCC activity and progression. A similar immune-capture approach targeting CD45 on plasma-derived exosomes enabled separation of CD45(+) hematopoietic cell-derived exosomes and CD45(-) TEX-enriched exosomes [76].

Exosomes present in plasma of HNSCC patients resemble a mix of TEX and non-TEX. Although TEX might serve as biomarkers for tumor status, exosomes produced from immune cells can serve as biomarkers for immune dysfunction [20,80]. Immune affinity-based capture with CD3 antibodies was used to separate T cell-derived CD3(+) exosomes from CD3(-) exosomes [23,81]. CD3(-) exosomes were $\mathrm{CD} 44 \mathrm{v} 3$ positive and thus largely tumor derived. Both exosome subsets carried immune regulatory proteins such as PD-L1, CTLA-4, COX-2, or CD15s and induced apoptosis of activated $\mathrm{T}$ cells [23]. The cargo of both CD3(+) and CD3(-) exosomes correlated with tumor stage and nodal status albeit the associations were weaker for the CD3(-), tumor-enriched fraction. Patients with high-stage disease or lymph node metastasis had higher levels of immune-suppressive and lower levels of immune-stimulatory markers compared to patients with low-stage disease or absence of lymph node metastasis. CD3(-) exosomes from patients with advanced disease carried the highest levels of enzymatically active CD39 and CD73 [81]. These exosomes spontaneously produced immune-suppressive adenosine in the presence of exogenous adenosine triphosphate (ATP) and induced adenosine production in Treg, as previously reported for total exosomes from plasma of HNSCC patients [82]. In contrast, CD3(+) exosomes from patients with early disease carried significantly higher levels of adenosine deaminase (ADA) and CD26, involved in adenosine degradation, compared 
to $\mathrm{CD} 3(+)$ exosomes from patients with advanced disease, indicating that the latter bear higher immune suppression [81]. By separating T cell-derived CD3(+) and TEX-enriched CD3(-) exosome subsets, simultaneous assessment of immune cell competence and tumor status as well as tumor-induced immune suppression was feasible.

In HNSCC, altered natural killer (NK) cell functions strongly contribute to the immune suppressive, protumorigenic TME [83-85]. NK cells express the Fc receptor CD16, hence they are able to participate in antibody-dependent cell-mediated cytotoxicity (ADCC) [86]. Recent data showed that CD16 is also present on exosomes derived from plasma of HNSCC patients, and CD16 levels were higher on total exosomes compared to TEX [87]. Further, CD16 levels on total exosomes but not TEX correlated with tumor stage and tumor aggressiveness. Patients with high and advanced tumor stages had significantly higher CD16 levels on total exosomes compared to low-stage patients. CD16-positive exosomes emerged as mediators of immune suppression as they could mimic NK cells in their function of cross-linking with antibody-coated malignant cells without implementing their cytotoxic function. Further, CD16-positive exosomes might reduce the efficacy of antibody therapies by serving as antibody-decoy as described for immune checkpoint inhibition with trastuzumab (anti-HER2 receptor monoclonal antibody) [88].

A summary of TEX and non-TEX interactions involved in tumor progression and immune suppression is presented in Figure 3; Figure 4.

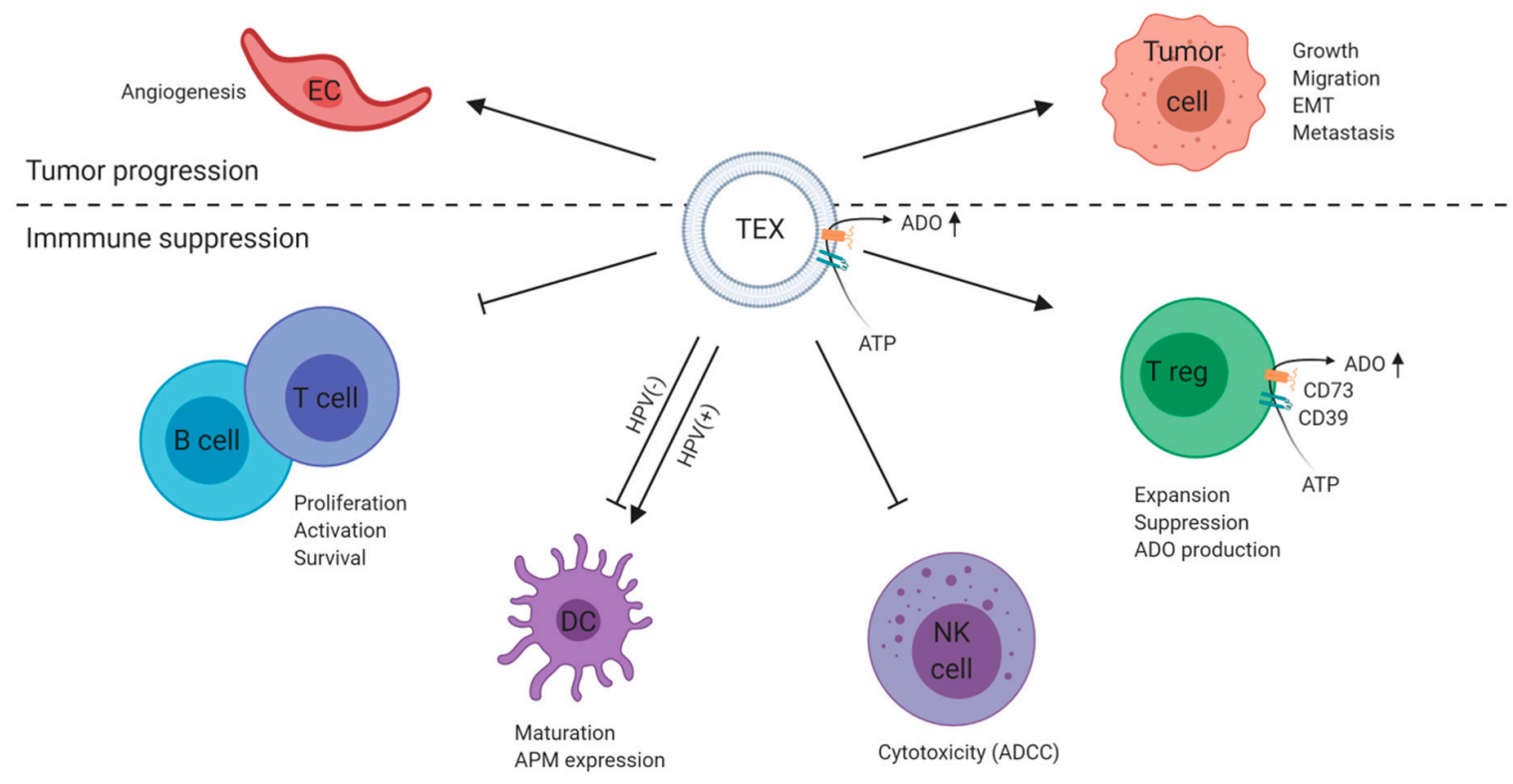

Figure 3. Summary of tumor-derived exosomes (TEX) interactions in head and neck squamous cell carcinomas (HNSCC). TEX produced by parental tumor cells mediate intercellular communication and play a key role in tumor progression and immune suppression. TEX induce angiogenesis by reprogramming of endothelial cells (EC) [37] and growth, migration, and metastasis of parental tumor cells [38-40,42]. Further, TEX alter the function of recipient immune cells resulting in immune dysfunction. They reduce lymphocyte proliferation and induce lymphocyte apoptosis [15,23,27,31-33], alter maturation of dendritic cells (DCs) and the expression of antigen-processing machinery components on DCs depending on the TEX HPV profile $[48,49]$, and induce suppression of cytotoxicity in natural killer (NK) cells $[15,27]$. TEX carry enzymatically active CD39 and CD73 on their surface, thus being able to produce immune-suppressive adenosine $[15,81,82]$. Additionally, TEX promote expansion, suppressive activity, and adenosine production in regulatory T cells (Treg) [31-35]. Figure is created with BioRender. 


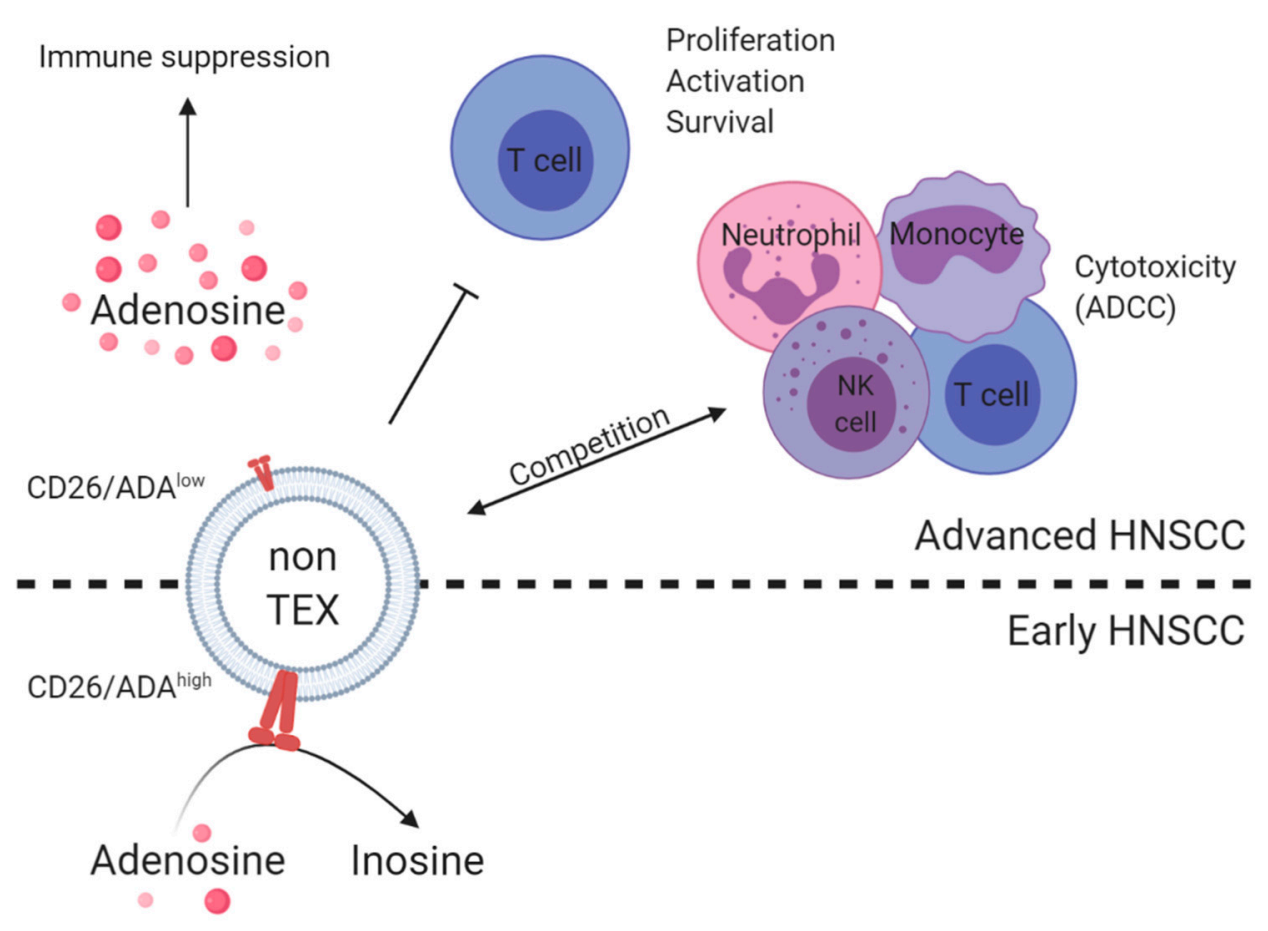

Figure 4. Summary of non-TEX interactions in HNSCC. Non-TEX, mainly immune cell-derived exosomes, contribute to the immune suppression in HNSCC and have a dual role in early versus advanced disease. Although non-TEX from plasma of patients with early HNSCC have high levels of CD26 and adenosine deaminase (ADA), which degrade immune-suppressive adenosine, non-TEX from plasma of patients with advanced HNSCC have low levels of CD26 and ADA resulting in high levels of immune-suppressive adenosine in those patients [81]. Further, the cargo of non-TEX correlated with advanced HNSCC regarding the inhibition of effector T cells [23] and the presence of CD16, which presumably competes with immune cells for antibody-dependent cellular cytotoxicity (ADCC) [87]. Figure is created with BioRender.

\section{Exosomes as Biomarkers and Players in Response to Therapy and Outcome}

Evidence from studies on cell-line-derived TEX (Table 1) suggests the involvement of exosomes in the effective treatment of HNSCC, including resistance to chemo- and radiotherapy. In particular, TEX derived from cisplatin-resistant OSCC cell lines were found to induce chemoresistance in platin-naive OSCC cells and decrease DNA damage signaling in response to cisplatin [51]. Similarly, TEX derived from cisplatin-resistant cancer-associated fibroblasts conferred chemoresistance and an aggressive phenotype in HNSCC cells by transfer of functional miR-196a [52]. Radioresistant ESCC cells were found to show differential miRNA expression profile and exosomal miR-339-5p was supposed to mediate regulation of radiosensitivity [53]. Further, the proteomic profile of TEX released from irradiated HNSCC cells was significantly altered compared to TEX from nonirradiated cells $[54,55]$. Overexpressed proteins were assigned to cell division, DNA repair, and metabolism of radical oxygen species, indicating that the proteomic profile of TEX released by irradiated cells reflects radiation-induced changes of cellular processes [54,55]. Even more, TEX derived from irradiated HNSCC cells promoted proliferation and conferred a migratory phenotype to recipient cancer cells $[56,57]$. Overall, these studies on cell-line derived TEX indicate that exosomes play a functional role in the response of tumor cells to chemo- and radiotherapy.

Rodrigues-Junior et al. analyzed the ability of exosomes to predict therapy outcome by analyzing pooled plasma samples from locally advanced HNSCC patients who had complete or incomplete response to chemoradiation therapy [89]. They identified a different proteomic profile between exosomes derived from responders and nonresponders. In chemoradiosensitive responders, proteins clustered in pathways related to FAS, p53, and apoptosis signaling. In chemoradioresistant 
nonresponders, proteins clustered in pathways related to tumorigenesis and angiogenesis pathways. These findings suggest that the content of circulating plasma-derived exosomes has a relevant function in the treatment response of HNSCC patients.

The role of exosomes and their molecular cargo for monitoring patient's response to therapy has been studied in a small cohort of patients with recurrent, therapy-refractive HNSCC undergoing photodynamic therapy (PDT) [24]. PDT is a palliative treatment option in which, after accumulation of a photosensitizer in the tumor, light activation induces a photochemical reaction with the production of cytotoxic reactive oxygen species. This results in tumor cell damage, local inflammation, and activation of innate and adaptive immune responses with the long-term development of an antitumor immunity [90,91]. Exosomes isolated from plasma of patients treated with PDT at different time points before and after therapy were analyzed regarding their potential to regulate epithelial-mesenchymal transition (EMT), a process conversing tumors from an epithelial to a highly aggressive and invasive mesenchymal phenotype [92]. Before therapy, exosomes from all patients showed a strong mesenchymal profile. However, after therapy, levels of the mesenchymal marker $\mathrm{N}$-cadherin decreased, whereas levels of the epithelial marker E-cadherin showed a significant increase. Furthermore, the known EMT inducer TGF- $\beta$ was significantly reduced in exosomes after PDT. These exosomes were also able to either promote or suppress EMT in recipient tumor cells dependent on the time point of exosome harvesting before or after PDT. This dual potential of exosomes to modulate EMT in a TGF- $\beta$ related manner suggested that exosomes contributed to the mesenchymal to epithelial transition of the tumor responding to PDT.

A recent study evaluated the predictive value of TEX and T cell-derived exosomes (separated using CD3 capture) on therapy response in HNSCC patients treated with cetuximab, ipilimumab, and radiation in a Phase I trial [22]. Exosomes were used to discriminate between patients whose disease recurred within 2 years and patients who remained disease-free. The TEX/total exosome ratio was assessed using the abovementioned microarray containing an antitumor antibody cocktail. Only patients with recurrence showed a significant increase of TEX levels after therapy compared to baseline, whereas disease-free patients had reduced TEX levels. Further, levels of CD3(+) exosomes remained unchanged throughout therapy in disease-free patients, whereas they were elevated during therapy in patients with recurrence. CD3(+)15s(+) Treg-derived exosomes seemed to contribute to this increase of $\mathrm{CD} 3(+)$ exosomes. Overall, these data suggest that exosomes can serve as biomarkers for monitoring patients' response to oncological therapy.

Until now, therapy-induced changes in exosomes have largely been studied using in vitro cell lines, and only a few studies were performed with exosomes isolated from plasma of patients. Despite the small patient cohorts, these results are promising and larger patient cohorts need to be investigated to validate exosomes as biomarkers for therapy response and outcome.

Table 3 provides an overview of the presented studies on plasma or serum-derived exosomes of HNSCC patients and highlights the analyzed exosome subsets and biomolecules as well as the outcome of the study. 
Table 3. Exosome studies involving patients.

\begin{tabular}{|c|c|c|c|c|c|c|c|}
\hline $\begin{array}{l}\text { Exosome } \\
\text { Source }\end{array}$ & Isolation Method & $\begin{array}{l}\text { Exosome } \\
\text { Subset }\end{array}$ & Methods & Molecules & Outcome & Prediction & Reference \\
\hline $\begin{array}{l}\text { Plasma of } \\
\text { HNSCC } \\
\text { patients }\end{array}$ & $\begin{array}{l}\text { Differential } \\
\text { centrifugation and } \\
\text { mini-SEC }\end{array}$ & Total exosomes & $\begin{array}{l}\text { Nanoparticle } \\
\text { tracking, western } \\
\text { blot, functional } \\
\text { coincubation } \\
\text { assays }\end{array}$ & $\begin{array}{l}\text { - (Establishment } \\
\text { of mini-SEC) }\end{array}$ & $\begin{array}{l}\text { Mini-SEC allows for simple and } \\
\text { reproducible isolation from human plasma } \\
\text { of exosomes retaining structural integrity } \\
\text { and functional activity. }\end{array}$ & - & [27] \\
\hline $\begin{array}{c}\text { Plasma of } \\
\text { HNSCC } \\
\text { patients, } n=38\end{array}$ & $\begin{array}{l}\text { Differential } \\
\text { centrifugation and } \\
\text { mini-SEC }\end{array}$ & Total exosomes & $\begin{array}{l}\text { Western blot, } \\
\text { functional } \\
\text { coincubation } \\
\text { assays }\end{array}$ & $\begin{array}{l}\text { - (Exosome- } \\
\text { mediated } \\
\text { immune } \\
\text { suppression) }\end{array}$ & $\begin{array}{l}\text { Patients with active disease (AD) had } \\
\text { significantly higher exosome levels } \\
\text { compared to patients with nonevident } \\
\text { disease (NED). Exosomes from patients with } \\
\text { AD mediated stronger immune suppression } \\
\text { than exosomes from patients with NED. }\end{array}$ & $\begin{array}{l}\text { Tumor } \\
\text { progression/ } \\
\text { disease activity } \\
\text { and immune } \\
\text { status }\end{array}$ & [15] \\
\hline $\begin{array}{c}\text { Plasma of } \\
\text { HNSCC } \\
\text { patients, } n=40\end{array}$ & $\begin{array}{l}\text { Differential } \\
\text { centrifugation and } \\
\text { mini-SEC }\end{array}$ & Total exosomes & $\begin{array}{l}\text { On-bead flow } \\
\text { cytometry, and } \\
\text { functional } \\
\text { coincubation } \\
\text { assays }\end{array}$ & PD-L1 & $\begin{array}{l}\text { Levels of PD-L1 on exosomes correlated } \\
\text { with disease activity, UICC stage, and the } \\
\text { presence of lymph node metastasis. In } \\
\text { contrast, plasma levels of soluble PD-L1 did } \\
\text { not correlate with any clinicopathological } \\
\text { data. High PD-L1 levels, but not low PD-L1 } \\
\text { level, exosomes suppressed T cell activity, } \\
\text { which could be attenuated with an } \\
\text { anti-PD-1 antibody. }\end{array}$ & $\begin{array}{c}\text { Tumor } \\
\text { progression/ } \\
\text { disease activity }\end{array}$ & [21] \\
\hline $\begin{array}{l}\text { Plasma of OSCC } \\
\text { patients, } n=108\end{array}$ & $\begin{array}{l}\text { ExoQuick Exosome } \\
\text { Precipitation Kit } \\
\text { (System } \\
\text { Biosciences) }\end{array}$ & Total exosomes & $\begin{array}{l}\text { miRNA } \\
\text { sequencing }\end{array}$ & miR-21 & $\begin{array}{l}\text { Exosomal miR-21 levels correlated with } \\
\text { advanced T classification, the presence of } \\
\text { lymph node metastasis, and tumor } \\
\text { HIF- } 1 \alpha / 2 \alpha \text { expression. }\end{array}$ & $\begin{array}{c}\text { Tumor } \\
\text { progression/ } \\
\text { disease activity }\end{array}$ & [42] \\
\hline $\begin{array}{l}\text { Serum of LSCC } \\
\text { patients, } n=52\end{array}$ & $\begin{array}{l}\text { ExoQuick Exosome } \\
\text { Precipitation Kit } \\
\text { (System } \\
\text { Biosciences) }\end{array}$ & Total exosomes & $\begin{array}{c}\text { miRNA analysis } \\
\text { (RT-PCR) }\end{array}$ & miR-21 & $\begin{array}{l}\text { Exosomal miR-21 and HOTAIR levels } \\
\text { correlated with advanced T classification } \\
\text { and UICC high stage. }\end{array}$ & $\begin{array}{c}\text { Tumor } \\
\text { progression/ } \\
\text { disease activity }\end{array}$ & [70] \\
\hline $\begin{array}{l}\text { Serum of ESCC } \\
\text { patients, } n=51\end{array}$ & $\begin{array}{l}\text { ExoQuick Exosome } \\
\text { Precipitation Kit } \\
\text { (System } \\
\text { Biosciences) }\end{array}$ & Total exosomes & $\begin{array}{l}\text { miRNA analysis } \\
\text { (RT-PCR) }\end{array}$ & miR-21 & $\begin{array}{l}\text { Exosomal miR-21 levels correlated with } \\
\text { advanced T classification, positive lymph } \\
\text { node status, and the presence of metastasis. }\end{array}$ & $\begin{array}{c}\text { Tumor } \\
\text { progression/ } \\
\text { disease activity }\end{array}$ & [71] \\
\hline
\end{tabular}


Table 3. Cont

\begin{tabular}{|c|c|c|c|c|c|c|c|}
\hline $\begin{array}{l}\text { Exosome } \\
\text { Source }\end{array}$ & Isolation Method & $\begin{array}{c}\text { Exosome } \\
\text { Subset }\end{array}$ & Methods & Molecules & Outcome & Prediction & Reference \\
\hline $\begin{array}{l}\text { Serum of OSCC } \\
\text { patients, } n=30\end{array}$ & $\begin{array}{c}\text { ExoQuick Exosome } \\
\text { Precipitation Kit } \\
\text { (System } \\
\text { Biosciences) }\end{array}$ & Total exosomes & $\begin{array}{l}\text { Quantitative } \\
\text { proteomics } \\
\text { approach and } \\
\text { bioinformatics }\end{array}$ & $\begin{array}{c}\text { PF4V1, CXCL7, } \\
\text { F13A1, and } \\
\text { ApoA1 }\end{array}$ & $\begin{array}{l}\text { PF4V1, CXCL7, F13A1, and ApoA1 were } \\
\text { correlated to tumor differentiation level, the } \\
\text { presence of lymph node metastasis, and the } \\
\text { abusus of alcohol and tobacco. Combining } \\
\text { these biomarkers improved diagnostic } \\
\text { accuracy compared to a single biomarker. }\end{array}$ & $\begin{array}{c}\text { Tumor } \\
\text { progression/ } \\
\text { disease activity }\end{array}$ & [72] \\
\hline $\begin{array}{c}\text { Plasma of } \\
\text { HNSCC } \\
\text { patients, } n=44\end{array}$ & $\begin{array}{c}\text { Differential } \\
\text { centrifugation and } \\
\text { mini-SEC }\end{array}$ & $\begin{array}{l}\text { Total exosomes, } \\
\text { T cell exosomes } \\
\quad \text { (CD3 } \\
\text { separation), and } \\
\text { TEX (CD44v3 } \\
\text { capture) }\end{array}$ & $\begin{array}{l}\text { On-bead flow } \\
\text { cytometry }\end{array}$ & $\mathrm{CD} 44 \mathrm{v} 3$ & $\begin{array}{l}\text { CD44v3 levels on CD3(-) exosomes were } \\
\text { higher in patients than in healthy donors } \\
\text { and correlated with UICC stage and lymph } \\
\text { node metastasis. The molecular profile of } \\
\text { CD44v3(+) exosomes was strongly } \\
\text { immune-suppressive and correlated with } \\
\text { disease stage and lymph node metastasis. }\end{array}$ & $\begin{array}{c}\text { Tumor } \\
\text { progression/ } \\
\text { disease activity }\end{array}$ & [76] \\
\hline $\begin{array}{c}\text { Plasma of } \\
\text { HNSCC } \\
\text { patients, } n=22\end{array}$ & $\begin{array}{c}\text { Differential } \\
\text { centrifugation and } \\
\text { mini-SEC }\end{array}$ & $\begin{array}{l}\text { T cell exosomes } \\
\text { and TEX (CD3 } \\
\text { separation) }\end{array}$ & $\begin{array}{l}\text { On-bead flow } \\
\text { cytometry and } \\
\text { functional } \\
\text { coincubation } \\
\text { assays }\end{array}$ & $\begin{array}{l}\text { PD-L1, CTLA-4, } \\
\text { COX-2, and } \\
\text { CD15s }\end{array}$ & $\begin{array}{l}\text { CD3 }(+) \text { and CD3(-) exosomes carried } \\
\text { immune regulatory proteins and induced } \\
\text { apoptosis of activated T cells. The cargo of } \\
\text { both subsets correlated with tumor stage } \\
\text { and nodal status albeit the associations were } \\
\text { weaker for the CD3(-) fraction. }\end{array}$ & $\begin{array}{c}\text { Tumor } \\
\text { progression/ } \\
\text { disease activity }\end{array}$ & [23] \\
\hline $\begin{array}{c}\text { Plasma of } \\
\text { HNSCC } \\
\text { patients, } n=14\end{array}$ & $\begin{array}{c}\text { Differential } \\
\text { centrifugation and } \\
\text { mini-SEC }\end{array}$ & $\begin{array}{l}\text { T cell exosomes } \\
\text { and TEX (CD3 } \\
\text { separation) }\end{array}$ & $\begin{array}{l}\text { On-bead flow } \\
\text { cytometry, } \\
\text { functional } \\
\text { coincubation } \\
\text { assays, and mass } \\
\text { spectrometry }\end{array}$ & $\begin{array}{c}\text { CD39, CD73, } \\
\text { ADA, CD26, } \\
\text { and adenosine }\end{array}$ & $\begin{array}{c}\text { High CD39/CD73 levels and adenosine } \\
\text { production were found in patients with } \\
\text { UICC high stage. ADA/CD26 levels on } \\
\text { CD3(+) exosomes correlated with UICC low } \\
\text { stage. }\end{array}$ & $\begin{array}{l}\text { Tumor } \\
\text { progression/ } \\
\text { disease activity } \\
\text { and immune } \\
\text { status }\end{array}$ & [81] \\
\hline $\begin{array}{c}\text { Plasma of } \\
\text { HNSCC } \\
\text { patients, } n=14\end{array}$ & $\begin{array}{c}\text { Differential } \\
\text { centrifugation, SEC, } \\
\text { and } \\
\text { ultracentrifugation }\end{array}$ & Total exosomes & $\begin{array}{l}\text { Mass } \\
\text { spectrometry and } \\
\text { functional } \\
\text { coincubation } \\
\text { assays }\end{array}$ & CD39 and CD73 & $\begin{array}{l}\text { Exosomes carried enzymatically active } \\
\text { CD39 and CD73 and, when supplied with } \\
\text { exogenous ATP, hydrolyzed it to adenosine. }\end{array}$ & Immune status & [82] \\
\hline $\begin{array}{c}\text { Plasma of } \\
\text { HNSCC } \\
\text { patients, } n=53\end{array}$ & $\begin{array}{l}\text { Differential } \\
\text { centrifugation and } \\
\text { mini-SEC }\end{array}$ & $\begin{array}{l}\text { Total exosomes } \\
\text { and TEX } \\
\text { (CD44v3 } \\
\text { capture) }\end{array}$ & $\begin{array}{l}\text { On-bead flow } \\
\text { cytometry }\end{array}$ & CD16 & $\begin{array}{l}\text { CD16 on total exosomes but not TEX, } \\
\text { correlated with advanced T classification } \\
\text { and UICC high stage. }\end{array}$ & $\begin{array}{c}\text { Tumor } \\
\text { progression/ } \\
\text { disease activity }\end{array}$ & [87] \\
\hline
\end{tabular}


Table 3. Cont

\begin{tabular}{|c|c|c|c|c|c|c|c|}
\hline $\begin{array}{l}\text { Exosome } \\
\text { Source }\end{array}$ & Isolation Method & $\begin{array}{l}\text { Exosome } \\
\text { Subset }\end{array}$ & Methods & Molecules & Outcome & Prediction & Reference \\
\hline $\begin{array}{c}\text { Plasma of } \\
\text { HNSCC } \\
\text { patients } \\
\text { undergoing } \\
\text { chemoradiation } \\
\text { therapy (CRT), } \\
n=12\end{array}$ & $\begin{array}{l}\text { Beads coated with } \\
\text { cholera toxin chain } \\
\text { B (CTB) and } \\
\text { annexin } V(A V)\end{array}$ & $\begin{array}{c}\text { CTB- and } \\
\text { AV-exosomes }\end{array}$ & Antibody array & $\begin{array}{l}\text { List of potential } \\
\text { markers } \\
\text { analyzed by the } \\
\text { array }\end{array}$ & $\begin{array}{l}\text { Exosomes from responders and } \\
\text { nonresponders to CRT showed a different } \\
\text { proteomic profile. Differentially present } \\
\text { proteins in exosomes from responders and } \\
\text { nonresponders were associated to FAS, p53, } \\
\text { and apoptosis pathways or tumorigenesis } \\
\text { and angiogenesis, respectively. }\end{array}$ & $\begin{array}{l}\text { Therapy } \\
\text { response/ } \\
\text { outcome }\end{array}$ & [89] \\
\hline $\begin{array}{c}\text { Plasma of } \\
\text { HNSCC } \\
\text { patients } \\
\text { undergoing } \\
\text { photodynamic } \\
\text { therapy (PDT), } \\
n=9\end{array}$ & $\begin{array}{c}\text { Differential } \\
\text { centrifugation and } \\
\text { mini-SEC }\end{array}$ & Total exosomes & $\begin{array}{l}\text { On-bead flow } \\
\text { cytometry and } \\
\text { functional } \\
\text { coincubation } \\
\text { assays }\end{array}$ & $\begin{array}{l}\text { EMT-associated } \\
\text { markers (TGF } \beta, \\
\text { E-cadherin, and } \\
\text { N-cadherin) }\end{array}$ & $\begin{array}{l}\text { Exosomes harvested before PDT had a } \\
\text { mesenchymal profile and enhanced tumor } \\
\text { proliferation, migration, and invasion. In } \\
\text { contrast, exosomes harvested after PDT had } \\
\text { an epithelial profile, restored the epithelial } \\
\text { morphology of tumor cells, and inhibited } \\
\text { their proliferation, migration, and invasion. }\end{array}$ & $\begin{array}{l}\text { Therapy } \\
\text { response/ } \\
\text { outcome }\end{array}$ & [24] \\
\hline $\begin{array}{l}\text { Plasma of } \\
\text { HNSCC } \\
\text { patients } \\
\text { enrolled in a } \\
\text { phase I clinical } \\
\text { trial and } \\
\text { receiving } \\
\text { cetuximab, } \\
\text { ipilimumab, } \\
\text { and radiation, } \\
n=18\end{array}$ & $\begin{array}{c}\text { Differential } \\
\text { centrifugation and } \\
\text { mini-SEC }\end{array}$ & $\begin{array}{l}\text { T cell exosomes } \\
\text { and TEX (CD3 } \\
\text { separation) }\end{array}$ & $\begin{array}{l}\text { On-bead flow } \\
\text { cytometry and } \\
\text { antibody } \\
\text { microarray }\end{array}$ & $\begin{array}{l}\text { PD-L1, CTLA-4, } \\
\text { and CD15s }\end{array}$ & $\begin{array}{l}\text { In recurrent patients, TEX levels, total } \\
\text { CD3(+), CD3(-) PD-L1+, and CD3(+) } \\
\text { CD15s+ (Treg-derived) exosomes increased } \\
\text { from baseline levels. In disease-free patients, } \\
\text { TEX levels decreased, CD3(+) and CD3(+) } \\
\text { CD15s+ exosomes stabilized and CD3(+) } \\
\text { CTLA4+ exosomes declined after } \\
\text { ipilimumab therapy. }\end{array}$ & $\begin{array}{l}\text { Therapy } \\
\text { response/ } \\
\text { outcome and } \\
\text { disease } \\
\text { recurrence }\end{array}$ & [22] \\
\hline
\end{tabular}




\section{Exosomes as Therapeutic Vesicles}

Patients with metastatic or recurrent HNSCC often do not respond to conventional therapies or develop drug resistance. Targeted delivery of chemotherapeutics might increase the effectiveness of such treatments, prevent chemoresistance, and decrease cytotoxic side effects. Exosomes, as endogenous nanocarriers for various molecules, are emerging as drug delivery vehicles both for chemotherapeutics as well as therapeutic short interfering RNAs (siRNA) due to their low immunogenicity, strong ability to cross physiological barriers, good biodistribution, and bioavailability [93-95]. Their potential for drug delivery has been examined in several tumor entities such as pancreas carcinoma [96,97] and breast cancer [98,99], whereas studies on HNSCC are rare. Exosomes loaded with the chemotherapeutics doxorubicin or paclitaxel were shown to accumulate efficiently in target tumor tissues and inhibit tumor growth in a breast cancer mouse model without overt side effects [98,99]. In another study, incorporation of paclitaxel in exosomes increased its cytotoxicity against multidrug-resistant cancer cells [100], indicating the possibility to overcome drug resistance by the use of exosome-encapsulated chemotherapeutics. Exosomes carrying siRNAs specific to oncogenic Kras have been shown to suppress cancer in multiple mouse models of pancreatic cancer, significantly increasing overall survival [97]. The same study revealed enhanced retention of these exosomes, compared to liposomes, in the circulation of mice due to reduced clearance by the mononuclear phagocyte system. In fact, exosomes have already undergone clinical trials in melanoma [101], colorectal [102], and lung cancer [103,104]. Recent data showing that exosome-delivered miRNA-138 efficiently conferred its OSCC antitumor functions in vitro and in vivo support the presumption that exosomes have potential as delivery agents also in HNSCC [105]. Further, engineered exosomes have been considered as therapeutic anticancer vaccines for HPV-associated tumors [106]. This approach is based on the mutant HIV-1 negative regulatory factor ( $\mathrm{Nef}^{\mathrm{mut}}$ ) protein, which remarkably incorporates into exosomes and acts as an exosome-anchoring protein upon fusion with heterologous proteins $[107,108]$. Upon inoculation in mice, Nef ${ }^{\text {mut}} / \mathrm{HPV}$-E7 exosomes induced an E7-sepcific cytotoxic T lymphocyte (CTL) immune response [109]. Even more, intramuscular immunization of mice with a DNA vector encoding Nefmut fused to HPV-E7 provided the animals with a source of endogenously engineered EVs, induced an E7-specific CTL activity, and blocked growth of syngeneic tumor cells in immunized mice bearing subcutaneous HPV-positive tumors [110].

Given these intriguing findings, extensive investigations such as evaluation of exosome pharmacokinetics and quantitative analysis in biological fluids [111] are required and ongoing to implement exosome-based drug delivery for HNSCC.

\section{Conclusion and Outlook}

The unique molecular cargo of exosomes, either tumor or immune cell-derived, allows to alter the function of recipient cells. The diverse exosome-mediated changes in the TME contribute to tumor progression and immune suppression. Due to the importance of exosomes in HNSCC carcinogenesis and antitumor immune response, exosomes may serve as potential biomarkers of diagnosis, prognosis, and therapy response in HNSCC. Although first studies on exosomes isolated from patient's plasma show promising results, there is a need to validate the diagnostic and prognostic profile of exosomes in large patient cohorts and clinical trials. Further, studies need to explore the clinical application as therapeutic vesicles in HNSCC.

Author Contributions: Conceptualization: L.H. and M.-N.T.; writing-original draft preparation: L.H. and M.-N.T.; writing-review and editing: C.B., T.K.H., S.L., and J.M.V.; and supervision: M.-N.T. All authors have read and agreed to the published version of the manuscript.

Funding: This research was funded by Deutsche Forschungsgemeinschaft, grant number TH2172/2-1 to MNT.

Conflicts of Interest: The authors declare no conflicts of interest. The funders had no role in the design of the study; in the collection, analyses, or interpretation of data; in the writing of the manuscript, or in the decision to publish the results. 


\section{Abbreviations}

$\begin{array}{ll}\text { AD } & \text { Active disease } \\ \text { ADA } & \text { Adenosine deaminase } \\ \text { ADCC } & \text { Antibody-dependent cell-mediated cytotoxicity } \\ \text { ATP } & \text { Adenosine triphosphate } \\ \text { CSPG4 } & \text { Chondroitin sulfate proteoglycan } 4 \\ \text { CTL } & \text { Cytotoxic T lymphocyte } \\ \text { DC } & \text { Dendritic cell } \\ \text { EC } & \text { Endothelial cell } \\ \text { EMT } & \text { Epithelial-mesenchymal transition } \\ \text { ESCC } & \text { Esophageal squamous cell carcinoma } \\ \text { EV } & \text { Extracellular vesicle } \\ \text { HNSCC } & \text { Head and neck squamous cell carcinoma } \\ \text { HPV } & \text { Human papilloma virus } \\ \text { LSCC } & \text { Laryngeal squamous cell carcinoma } \\ \text { MISEV } & \text { Minimal information for studies of extracellular vesicles } \\ \text { MVB } & \text { Multivesicular body } \\ \text { NED } & \text { Nonevident disease } \\ \text { Nef } & \text { Negative regulatory factor } \\ \text { NK } & \text { Natural killer } \\ \text { OSCC } & \text { Oral squamous cell carcinoma } \\ \text { PDT } & \text { Photodynamic therapy } \\ \text { ROC } & \text { Receiver operating characteristic } \\ \text { SEC } & \text { Size exclusion chromatography } \\ \text { siRNA } & \text { Short interfering RNA } \\ \text { TEM } & \text { Transmission electron microscopy } \\ \text { TEX } & \text { Tumor-derived exosomes } \\ \text { TME } & \text { Tumor microenvironment } \\ \text { Treg } & \text { Regulatory T cells } \\ \text { UICC } & \text { Union for International Cancer Control } \\ \text { 4NQO } & \text { 4-nitroquinoline 1-oxide } \\ & \end{array}$

\section{References}

1. Ferris, R.L. Immunology and Immunotherapy of Head and Neck Cancer. J. Clin. Oncol. 2015, 33, 3293-3304. [CrossRef] [PubMed]

2. Mandal, R.; Şenbabaoğlu, Y.; Desrichard, A.; Havel, J.J.; Dalin, M.G.; Riaz, N.; Lee, K.-W.; Ganly, I.; Hakimi, A.A.; Chan, T.A.; et al. The head and neck cancer immune landscape and its immunotherapeutic implications. JCI Insight 2016, 1. [CrossRef] [PubMed]

3. Whiteside, T.L. Head and Neck Carcinoma Immunotherapy: Facts and Hopes. Clin. Cancer Res. 2018, 24, 6-13. [CrossRef] [PubMed]

4. Forster, M.D.; Devlin, M.-J. Immune Checkpoint Inhibition in Head and Neck Cancer. Front. Oncol. 2018, 8, 310. [CrossRef] [PubMed]

5. Wei, S.C.; Duffy, C.R.; Allison, J.P. Fundamental Mechanisms of Immune Checkpoint Blockade Therapy. Cancer Discov. 2018, 8, 1069-1086. [CrossRef]

6. Brahmer, J.R.; Drake, C.G.; Wollner, I.; Powderly, J.D.; Picus, J.; Sharfman, W.H.; Stankevich, E.; Pons, A.; Salay, T.M.; McMiller, T.L.; et al. Phase I study of single-agent anti-programmed death-1 (MDX-1106) in refractory solid tumors: Safety, clinical activity, pharmacodynamics, and immunologic correlates. J. Clin. Oncol. 2010, 28, 3167-3175. [CrossRef]

7. Ferris, R.L.; Blumenschein, G., Jr.; Fayette, J.; Guigay, J.; Colevas, A.D.; Licitra, L.; Harrington, K.; Kasper, S.; Vokes, E.E.; Even, C.; et al. Nivolumab for Recurrent Squamous-Cell Carcinoma of the Head and Neck. N. Engl. J. Med. 2016, 375, 1856-1867. [CrossRef] 
8. Chow, L.Q.M.; Haddad, R.; Gupta, S.; Mahipal, A.; Mehra, R.; Tahara, M.; Berger, R.; Eder, J.P.; Burtness, B.; Lee, S.-H.; et al. Antitumor Activity of Pembrolizumab in Biomarker-Unselected Patients With Recurrent and/or Metastatic Head and Neck Squamous Cell Carcinoma: Results From the Phase Ib KEYNOTE-012 Expansion Cohort. J. Clin. Oncol. 2016, 34, 3838-3845. [CrossRef]

9. Burtness, B.; Harrington, K.J.; Greil, R.; Soulières, D.; Tahara, M.; de Castro, G.; Psyrri, A.; Basté, N.; Neupane, P.; Bratland, A.; et al. Pembrolizumab alone or with chemotherapy versus cetuximab with chemotherapy for recurrent or metastatic squamous cell carcinoma of the head and neck (KEYNOTE-048): A randomised, open-label, phase 3 study. Lancet 2019, 394, 1915-1928. [CrossRef]

10. Xie, X.; O'Neill, W.; Pan, Q. Immunotherapy for head and neck cancer: The future of treatment? Expert Opin. Biol. Ther. 2017, 17, 701-708. [CrossRef]

11. Milane, L.; Singh, A.; Mattheolabakis, G.; Suresh, M.; Amiji, M.M. Exosome mediated communication within the tumor microenvironment. J. Control Release 2015, 219, 278-294. [CrossRef] [PubMed]

12. Abels, E.R.; Breakefield, X.O. Introduction to Extracellular Vesicles: Biogenesis, RNA Cargo Selection, Content, Release, and Uptake. Cell. Mol. Neurobiol. 2016, 36, 301-312. [CrossRef] [PubMed]

13. Théry, C.; Zitvogel, L.; Amigorena, S. Exosomes: Composition, biogenesis and function. Nat. Rev. Immunol. 2002, 2, 569-579. [CrossRef] [PubMed]

14. Kalluri, R. The biology and function of exosomes in cancer. J. Clin. Investig. 2016, 126, 1208-1215. [CrossRef]

15. Ludwig, S.; Floros, T.; Theodoraki, M.-N.; Hong, C.-S.; Jackson, E.K.; Lang, S.; Whiteside, T.L. Suppression of Lymphocyte Functions by Plasma Exosomes Correlates with Disease Activity in Patients with Head and Neck Cancer. Clin. Cancer Res. 2017, 23, 4843-4854. [CrossRef]

16. Whiteside, T.L. The effect of tumor-derived exosomes on immune regulation and cancer immunotherapy. Future Oncol. 2017, 13, 2583-2592. [CrossRef]

17. Whiteside, T.L. Exosomes carrying immunoinhibitory proteins and their role in cancer. Clin. Exp. Immunol. 2017, 189, 259-267. [CrossRef]

18. Ruivo, C.F.; Adem, B.; Silva, M.; Melo, S.A. The Biology of Cancer Exosomes: Insights and New Perspectives. Cancer Res. 2017, 77, 6480-6488. [CrossRef]

19. Whiteside, T.L. The potential of tumor-derived exosomes for noninvasive cancer monitoring: An update. Expert Rev. Mol. Diagn. 2018, 18, 1029-1040. [CrossRef]

20. Whiteside, T.L. The emerging role of plasma exosomes in diagnosis, prognosis and therapies of patients with cancer. Contemp. Oncol. (Poznan, Poland) 2018, 22, 38-40. [CrossRef]

21. Theodoraki, M.-N.; Yerneni, S.S.; Hoffmann, T.K.; Gooding, W.E.; Whiteside, T.L. Clinical Significance of PD-L1+ Exosomes in Plasma of Head and Neck Cancer Patients. Clin. Cancer Res. 2018, 24, 896-905. [CrossRef] [PubMed]

22. Theodoraki, M.-N.; Yerneni, S.S.; Gooding, W.E.; Ohr, J.; Clump, D.A.; Bauman, J.E.; Ferris, R.L.; Whiteside, T.L. Circulating exosomes measure responses to therapy in head and neck cancer patients treated with cetuximab, ipilimumab, and IMRT. Oncoimmunology 2019, 8, 1593805. [CrossRef] [PubMed]

23. Theodoraki, M.-N.; Hoffmann, T.K.; Whiteside, T.L. Separation of plasma-derived exosomes into CD3((+)) and CD3((-)) fractions allows for association of immune cell and tumour cell markers with disease activity in HNSCC patients. Clin. Exp. Immunol. 2018, 192, 271-283. [CrossRef]

24. Theodoraki, M.-N.; Yerneni, S.S.; Brunner, C.; Theodorakis, J.; Hoffmann, T.K.; Whiteside, T.L. Plasma-derived Exosomes Reverse Epithelial-to-Mesenchymal Transition after Photodynamic Therapy of Patients with Head and Neck Cancer. Oncoscience 2018, 5, 75-87. [CrossRef] [PubMed]

25. Li, P.; Kaslan, M.; Lee, S.H.; Yao, J.; Gao, Z. Progress in Exosome Isolation Techniques. Theranostics 2017, 7, 789-804. [CrossRef]

26. Konoshenko, M.Y.; Lekchnov, E.A.; Vlassov, A.V.; Laktionov, P.P. Isolation of Extracellular Vesicles: General Methodologies and Latest Trends. Biomed Res. Int. 2018, 2018, 8545347. [CrossRef]

27. Hong, C.-S.; Funk, S.; Muller, L.; Boyiadzis, M.; Whiteside, T.L. Isolation of biologically active and morphologically intact exosomes from plasma of patients with cancer. J. Extracell. Vesicles 2016, 5, 29289. [CrossRef]

28. Théry, C.; Witwer, K.W.; Aikawa, E.; Alcaraz, M.J.; Anderson, J.D.; Andriantsitohaina, R. Minimal information for studies of extracellular vesicles 2018 (MISEV2018): A position statement of the International Society for Extracellular Vesicles and update of the MISEV2014 guidelines. J. Extracell. Vesicles 2018, 7, 1535750. [CrossRef] 
29. Whiteside, T.L. Tumor-Derived Exosomes and Their Role in Tumor-Induced Immune Suppression. Vaccines 2016, 4, 35. [CrossRef]

30. Ludwig, N.; Razzo, B.M.; Yerneni, S.S.; Whiteside, T.L. Optimization of cell culture conditions for exosome isolation using mini-size exclusion chromatography (mini-SEC). Exp. Cell Res. 2019, 378, 149-157. [CrossRef]

31. Wieckowski, E.U.; Visus, C.; Szajnik, M.; Szczepanski, M.J.; Storkus, W.J.; Whiteside, T.L. Tumor-derived microvesicles promote regulatory $\mathrm{T}$ cell expansion and induce apoptosis in tumor-reactive activated CD8+ T lymphocytes. J. Immunol. 2009, 183, 3720-3730. [CrossRef] [PubMed]

32. Muller, L.; Mitsuhashi, M.; Simms, P.; Gooding, W.E.; Whiteside, T.L. Tumor-derived exosomes regulate expression of immune function-related genes in human T cell subsets. Sci. Rep. 2016, 6, 20254. [CrossRef] [PubMed]

33. Muller, L.; Simms, P.; Hong, C.-S.; Nishimura, M.I.; Jackson, E.K.; Watkins, S.C.; Whiteside, T.L. Human tumor-derived exosomes (TEX) regulate Treg functions via cell surface signaling rather than uptake mechanisms. Oncoimmunology 2017, 6, e1261243. [CrossRef] [PubMed]

34. Mrizak, D.; Martin, N.; Barjon, C.; Jimenez-Pailhes, A.-S.; Mustapha, R.; Niki, T.; Guigay, J.; Pancré, V.; de Launoit, Y.; Busson, P.; et al. Effect of Nasopharyngeal Carcinoma-Derived Exosomes on Human Regulatory T Cells. JNCI J. Natl. Cancer Inst. 2014, 107, dju363. [CrossRef] [PubMed]

35. Szajnik, M.; Czystowska, M.; Szczepanski, M.J.; Mandapathil, M.; Whiteside, T.L. Tumor-Derived Microvesicles Induce, Expand and Up-Regulate Biological Activities of Human Regulatory T Cells (Treg). PLOS ONE 2010, 5, e11469. [CrossRef]

36. Madeo, M.; Colbert, P.L.; Vermeer, D.W.; Lucido, C.T.; Cain, J.T.; Vichaya, E.G.; Grossberg, A.J.; Muirhead, D.; Rickel, A.P.; Hong, Z.; et al. Cancer exosomes induce tumor innervation. Nat. Commun. 2018, 9, 4284. [CrossRef]

37. Ludwig, N.; Yerneni, S.S.; Razzo, B.M.; Whiteside, T.L. Exosomes from HNSCC Promote Angiogenesis through Reprogramming of Endothelial Cells. Mol. Cancer Res. 2018, 16. [CrossRef]

38. Sakha, S.; Muramatsu, T.; Ueda, K.; Inazawa, J. Exosomal microRNA miR-1246 induces cell motility and invasion through the regulation of DENND2D in oral squamous cell carcinoma. Sci. Rep. 2016, 6, 38750. [CrossRef]

39. Fujiwara, T.; Eguchi, T.; Sogawa, C.; Ono, K.; Murakami, J.; Ibaragi, S.; Asaumi, J.; Calderwood, S.K.; Okamoto, K.; Kozaki, K. Carcinogenic epithelial-mesenchymal transition initiated by oral cancer exosomes is inhibited by anti-EGFR antibody cetuximab. Oral Oncol. 2018, 86, 251-257. [CrossRef]

40. Qadir, F.; Aziz, M.A.; Sari, C.P.; Ma, H.; Dai, H.; Wang, X.; Raithatha, D.; Da Silva, L.G.L.; Hussain, M.; Poorkasreiy, S.P.; et al. Transcriptome reprogramming by cancer exosomes: Identification of novel molecular targets in matrix and immune modulation. Mol. Cancer 2018, 17, 97. [CrossRef]

41. Lu, X.; Kang, Y. Hypoxia and Hypoxia-Inducible Factors: Master Regulators of Metastasis. Clin. Cancer Res. 2010, 16, 5928-5935. [CrossRef] [PubMed]

42. Li, L.; Li, C.; Wang, S.; Wang, Z.; Jiang, J.; Wang, W.; Li, X.; Chen, J.; Liu, K.; Li, C.; et al. Exosomes Derived from Hypoxic Oral Squamous Cell Carcinoma Cells Deliver miR-21 to Normoxic Cells to Elicit a Prometastatic Phenotype. Cancer Res. 2016, 76, 1770-1780. [CrossRef] [PubMed]

43. Sento, S.; Sasabe, E.; Yamamoto, T. Application of a Persistent Heparin Treatment Inhibits the Malignant Potential of Oral Squamous Carcinoma Cells Induced by Tumor Cell-Derived Exosomes. PLoS ONE 2016, 11, e0148454. [CrossRef] [PubMed]

44. Razzo, B.M.; Ludwig, N.; Hong, C.-S.; Sharma, P.; Fabian, K.P.; Fecek, R.J.; Storkus, W.J.; Whiteside, T.L. Tumor-derived exosomes promote carcinogenesis of murine oral squamous cell carcinoma. Carcinogenesis 2019. [CrossRef] [PubMed]

45. Kanojia, D.; Vaidya, M.M. 4-Nitroquinoline-1-oxide induced experimental oral carcinogenesis. Oral Oncol. 2006, 42, 655-667. [CrossRef]

46. Hawkins, B.L.; Heniford, B.W.; Ackermann, D.M.; Leonberger, M.; Martinez, S.A.; Hendler, F.J. 4NQO carcinogenesis: A mouse model of oral cavity squamous cell carcinoma. Head Neck 1994, 16, 424-432. [CrossRef]

47. Yang, Z.; Guan, B.; Men, T.; Fujimoto, J.; Xu, X. Comparable molecular alterations in 4-nitroquinoline 1-oxide-induced oral and esophageal cancer in mice and in human esophageal cancer, associated with poor prognosis of patients. In Vivo 2013, 27, 473-484. 
48. Ludwig, S.; Sharma, P.; Theodoraki, M.-N.; Pietrowska, M.; Yerneni, S.S.; Lang, S.; Ferrone, S.; Whiteside, T.L. Molecular and Functional Profiles of Exosomes From HPV(+) and HPV(-) Head and Neck Cancer Cell Lines. Front. Oncol. 2018, 8, 445. [CrossRef]

49. Ludwig, S.; Marczak, L.; Sharma, P.; Abramowicz, A.; Gawin, M.; Widlak, P.; Whiteside, T.L.; Pietrowska, M. Proteomes of exosomes from $\mathrm{HPV}(+)$ or $\mathrm{HPV}(-)$ head and neck cancer cells: Differential enrichment in immunoregulatory proteins. Oncoimmunology 2019, 8, 1593808. [CrossRef]

50. Tong, F.; Mao, X.; Zhang, S.; Xie, H.; Yan, B.; Wang, B.; Sun, J.; Wei, L. HPV + HNSCC-derived exosomal miR-9 induces macrophage M1 polarization and increases tumor radiosensitivity. Cancer Lett. 2020, 478, 34-44. [CrossRef]

51. Liu, T.; Chen, G.; Sun, D.; Lei, M.; Li, Y.; Zhou, C.; Li, X.; Xue, W.; Wang, H.; Liu, C.; et al. Exosomes containing miR-21 transfer the characteristic of cisplatin resistance by targeting PTEN and PDCD4 in oral squamous cell carcinoma. Acta Biochim. Biophys. Sin. (Shanghai) 2017, 49, 808-816. [CrossRef]

52. Qin, X.; Guo, H.; Wang, X.; Zhu, X.; Yan, M.; Wang, X.; Xu, Q.; Shi, J.; Lu, E.; Chen, W.; et al. Exosomal miR-196a derived from cancer-associated fibroblasts confers cisplatin resistance in head and neck cancer through targeting CDKN1B and ING5. Genome Biol. 2019, 20, 12. [CrossRef] [PubMed]

53. Luo, A.; Zhou, X.; Shi, X.; Zhao, Y.; Men, Y.; Chang, X.; Chen, H.; Ding, F.; Li, Y.; Su, D.; et al. Exosome-derived miR-339-5p mediates radiosensitivity by targeting Cdc25A in locally advanced esophageal squamous cell carcinoma. Oncogene 2019, 38, 4990-5006. [CrossRef] [PubMed]

54. Abramowicz, A.; Wojakowska, A.; Marczak, L.; Lysek-Gladysinska, M.; Smolarz, M.; Story, M.D.; Polanska, J.; Widlak, P.; Pietrowska, M. Ionizing radiation affects the composition of the proteome of extracellular vesicles released by head-and-neck cancer cells in vitro. J. Radiat. Res. 2019, 60, 289-297. [CrossRef] [PubMed]

55. Jelonek, K.; Wojakowska, A.; Marczak, L.; Muer, A.; Tinhofer-Keilholz, I.; Lysek-Gladysinska, M.; Widlak, P.; Pietrowska, M. Ionizing radiation affects protein composition of exosomes secreted in vitro from head and neck squamous cell carcinoma. Acta Biochim. Pol. 2015, 62, 265-272. [CrossRef] [PubMed]

56. Mutschelknaus, L.; Azimzadeh, O.; Heider, T.; Winkler, K.; Vetter, M.; Kell, R.; Tapio, S.; Merl-Pham, J.; Huber, S.M.; Edalat, L.; et al. Radiation alters the cargo of exosomes released from squamous head and neck cancer cells to promote migration of recipient cells. Sci. Rep. 2017, 7, 12423. [CrossRef] [PubMed]

57. Mutschelknaus, L.; Peters, C.; Winkler, K.; Yentrapalli, R.; Heider, T.; Atkinson, M.J.; Moertl, S. Exosomes Derived from Squamous Head and Neck Cancer Promote Cell Survival after Ionizing Radiation. PLoS ONE 2016, 11, e0152213. [CrossRef]

58. Mork, J.; Lie, A.K.; Glattre, E.; Clark, S.; Hallmans, G.; Jellum, E.; Koskela, P.; Møller, B.; Pukkala, E.; Schiller, J.T.; et al. Human Papillomavirus Infection as a Risk Factor for Squamous-Cell Carcinoma of the Head and Neck. N. Engl. J. Med. 2001, 344, 1125-1131. [CrossRef]

59. Gillison, M.L.; Koch, W.M.; Capone, R.B.; Spafford, M.; Westra, W.H.; Wu, L.; Zahurak, M.L.; Daniel, R.W.; Viglione, M.; Symer, D.E.; et al. Evidence for a Causal Association Between Human Papillomavirus and a Subset of Head and Neck Cancers. JNCI J. Natl. Cancer Inst. 2000, 92, 709-720. [CrossRef]

60. Castellsagué, X.; Alemany, L.; Quer, M.; Halec, G.; Quirós, B.; Tous, S.; Clavero, O.; Alòs, L.; Biegner, T.; Szafarowski, T; et al. HPV Involvement in Head and Neck Cancers: Comprehensive Assessment of Biomarkers in 3680 Patients. JNCI J. Natl. Cancer Inst. 2016, 108. [CrossRef]

61. Boscolo-Rizzo, P.; Del Mistro, A.; Bussu, F.; Lupato, V.; Baboci, L.; Almadori, G.; DA Mosto, M.C.; Paludetti, G. New insights into human papillomavirus-associated head and neck squamous cell carcinoma. Acta Otorhinolaryngol. Ital. 2013, 33, 77-87.

62. Fakhry, C.; Westra, W.H.; Li, S.; Cmelak, A.; Ridge, J.A.; Pinto, H.; Forastiere, A.; Gillison, M.L. Improved Survival of Patients With Human Papillomavirus-Positive Head and Neck Squamous Cell Carcinoma in a Prospective Clinical Trial. JNCI J. Natl. Cancer Inst. 2008, 100, 261-269. [CrossRef]

63. Ang, K.K.; Harris, J.; Wheeler, R.; Weber, R.; Rosenthal, D.I.; Nguyen-Tân, P.F.; Westra, W.H.; Chung, C.H.; Jordan, R.C.; Lu, C.; et al. Human Papillomavirus and Survival of Patients with Oropharyngeal Cancer. N. Engl. J. Med. 2010, 363, 24-35. [CrossRef]

64. Economopoulou, P.; Kotsantis, I.; Psyrri, A. Special Issue about Head and Neck Cancers: HPV Positive Cancers. Int. J. Mol. Sci. 2020, 21, 3388. [CrossRef]

65. Cordonnier, M.; Nardin, C.; Chanteloup, G.; Derangere, V.; Algros, M.-P.; Arnould, L.; Garrido, C.; Aubin, F.; Gobbo, J. Tracking the evolution of circulating exosomal-PD-L1 to monitor melanoma patients. J. Extracell. Vesicles 2020, 9, 1710899. [CrossRef] 
66. Chen, G.; Huang, A.C.; Zhang, W.; Zhang, G.; Wu, M.; Xu, W.; Yu, Z.; Yang, J.; Wang, B.; Sun, H.; et al. Exosomal PD-L1 contributes to immunosuppression and is associated with anti-PD-1 response. Nature 2018, 560, 382-386. [CrossRef]

67. Li, C.; Li, C.; Zhi, C.; Liang, W.; Wang, X.; Chen, X.; Lv, T.; Shen, Q.; Song, Y.; Lin, D.; et al. Clinical significance of PD-L1 expression in serum-derived exosomes in NSCLC patients. J. Transl. Med. 2019, 17, 355. [CrossRef]

68. Sun, Z.; Shi, K.; Yang, S.; Liu, J.; Zhou, Q.; Wang, G.; Song, J.; Li, Z.; Zhang, Z.; Yuan, W. Effect of exosomal miRNA on cancer biology and clinical applications. Mol. Cancer 2018, 17, 147. [CrossRef]

69. Irimie-Aghiorghiesei, A.I.; Pop-Bica, C.; Pintea, S.; Braicu, C.; Cojocneanu, R.; Zimța, A.-A.; Gulei, D.; Slabý, O.; Berindan-Neagoe, I. Prognostic Value of MiR-21: An Updated Meta-Analysis in Head and Neck Squamous Cell Carcinoma (HNSCC). J. Clin. Med. 2019, 8, 2041. [CrossRef]

70. Wang, J.; Zhou, Y.; Lu, J.; Sun, Y.; Xiao, H.; Liu, M.; Tian, L. Combined detection of serum exosomal miR-21 and HOTAIR as diagnostic and prognostic biomarkers for laryngeal squamous cell carcinoma. Med. Oncol. 2014, 31, 1-8. [CrossRef]

71. Tanaka, Y.; Kamohara, H.; Kinoshita, K.; Kurashige, J.; Ishimoto, T.; Iwatsuki, M.; Watanabe, M.; Baba, H. Clinical impact of serum exosomal microRNA-21 as a clinical biomarker in human esophageal squamous cell carcinoma. Cancer 2013, 119, 1159-1167. [CrossRef] [PubMed]

72. Li, C.; Zhou, Y.; Liu, J.; Su, X.; Qin, H.; Huang, S.; Huang, X.; Zhou, N. Potential Markers from Serum-Purified Exosomes for Detecting Oral Squamous Cell Carcinoma Metastasis. Cancer Epidemiol. Prev. Biomark. 2019, 28, 1668-1681. [CrossRef] [PubMed]

73. Wang, X.; Wang, Y.; Yu, L.; Sakakura, K.; Visus, C.; Schwab, J.H.; Ferrone, C.R.; Favoino, E.; Koya, Y.; Campoli, M.R.; et al. CSPG4 in Cancer: Multiple Roles. Curr. Mol. Med. 2010, 10, 419-429. [CrossRef] [PubMed]

74. Campoli, M.R.; Chang, C.-C.; Kageshita, T.; Wang, X.; McCarthy, J.B.; Ferrone, S. Human High Molecular Weight-Melanoma-Associated Antigen (HMW-MAA): A Melanoma Cell Surface Chondroitin Sulfate Proteoglycan (MSCP) with Biological and Clinical Significance. Crit. Rev. Immunol. 2004, 24, 267-296. [CrossRef]

75. Sharma, P.; Ludwig, S.; Muller, L.; Hong, C.S.; Kirkwood, J.M.; Ferrone, S.; Whiteside, T.L. Immunoaffinity-based isolation of melanoma cell-derived exosomes from plasma of patients with melanoma. J. Extracell. vesicles 2018, 7, 1435138. [CrossRef]

76. Theodoraki, M.-N.; Matsumoto, A.; Beccard, I.; Hoffmann, T.K.; Whiteside, T.L. CD44v3 protein-carrying tumor-derived exosomes in HNSCC patients' plasma as potential noninvasive biomarkers of disease activity. Oncoimmunology 2020, 9, 1747732. [CrossRef]

77. Sagawa, K.; Uwa, N.; Daimon, T.; Sakagami, M.; Tsujimura, T. Expression of CD44 variant isoforms, CD44v3 and CD44v6, are associated with prognosis in nasopharyngeal carcinoma. J. Laryngol. Otol. 2016, 130, 843-849. [CrossRef]

78. Spiegelberg, D.; Kuku, G.; Selvaraju, R.; Nestor, M. Characterization of CD44 variant expression in head and neck squamous cell carcinomas. Tumour Biol. 2014, 35, 2053-2062. [CrossRef]

79. Wang, S.J.; Wreesmann, V.B.; Bourguignon, L.Y.W. Association of CD44 V3-containing isoforms with tumor cell growth, migration, matrix metalloproteinase expression, and lymph node metastasis in head and neck cancer. Head Neck 2007, 29, 550-558. [CrossRef]

80. Whiteside, T.L. Proteomic Analysis of Plasma-Derived Exosomes in Defining Their Role as Biomarkers of Disease Progression, Response to Therapy and Outcome. Proteomes 2019, 7, 27. [CrossRef]

81. Theodoraki, M.-N.; Hoffmann, T.K.; Jackson, E.K.; Whiteside, T.L. Exosomes in HNSCC plasma as surrogate markers of tumour progression and immune competence. Clin. Exp. Immunol. 2018, 194, 67-78. [CrossRef]

82. Schuler, P.J.; Saze, Z.; Hong, C.-S.; Muller, L.; Gillespie, D.G.; Cheng, D.; Harasymczuk, M.; Mandapathil, M.; Lang, S.; Jackson, E.K.; et al. Human CD4+ CD39+ regulatory T cells produce adenosine upon co-expression of surface CD73 or contact with CD73+ exosomes or CD73+ cells. Clin. Exp. Immunol. 2014, 177, 531-543. [CrossRef]

83. Wulff, S.; Pries, R.; Börngen, K.; Trenkle, T.; Wollenberg, B. Decreased levels of circulating regulatory NK cells in patients with head and neck cancer throughout all tumor stages. Anticancer. Res. 2009, 29, 3053-3057.

84. Watanabe, M.; Kono, K.; Kawaguchi, Y.; Mizukami, Y.; Mimura, K.; Maruyama, T.; Izawa, S.; Fujii, H. NK cell dysfunction with down-regulated CD16 and up-regulated CD56 molecules in patients with esophageal squamous cell carcinoma. Dis. Esophagus 2010, 23, 675-681. [CrossRef] 
85. Klöß, S.; Chambron, N.; Gardlowski, T.; Arseniev, L.; Koch, J.; Esser, R.; Glienke, W.; Seitz, O.; Köhl, U. Increased sMICA and TGF $\beta(1)$ levels in HNSCC patients impair NKG2D-dependent functionality of activated NK cells. Oncoimmunology 2015, 4, e1055993. [CrossRef]

86. Cooper, M.A.; Fehniger, T.A.; Caligiuri, M.A. The biology of human natural killer-cell subsets. Trends Immunol. 2001, 22, 633-640. [CrossRef]

87. Hofmann, L.; Ludwig, S.; Schuler, P.J.; Hoffmann, T.K.; Brunner, C.; Theodoraki, M.-N. The Potential of CD16 on Plasma-Derived Exosomes as a Liquid Biomarker in Head and Neck Cancer. Int. J. Mol. Sci. 2020, 21, 3739. [CrossRef]

88. Battke, C.; Ruiss, R.; Welsch, U.; Wimberger, P.; Lang, S.; Jochum, S.; Zeidler, R. Tumour exosomes inhibit binding of tumour-reactive antibodies to tumour cells and reduce ADCC. Cancer Immunol. Immunother. 2011, 60, 639-648. [CrossRef]

89. Rodrigues-Junior, D.M.; Tan, S.S.; de Souza Viana, L.; Carvalho, A.L.; Lim, S.K.; Iyer, N.G.; Vettore, A.L. A preliminary investigation of circulating extracellular vesicles and biomarker discovery associated with treatment response in head and neck squamous cell carcinoma. BMC Cancer 2019, 19, 373. [CrossRef]

90. Castano, A.P.; Mroz, P.; Hamblin, M.R. Photodynamic therapy and anti-tumour immunity. Nat. Rev. Cancer 2006, 6, 535-545. [CrossRef]

91. Garg, A.D.; Nowis, D.; Golab, J.; Agostinis, P. Photodynamic therapy: Illuminating the road from cell death towards anti-tumour immunity. Apoptosis 2010, 15, 1050-1071. [CrossRef] [PubMed]

92. Kalluri, R.; Weinberg, R.A. The basics of epithelial-mesenchymal transition. J. Clin. Invest. 2009, 119, 1420-1428. [CrossRef] [PubMed]

93. Liu, C.; Gao, H.; Lv, P.; Liu, J.; Liu, G. Extracellular vesicles as an efficient nanoplatform for the delivery of therapeutics. Hum. Vaccin. Immunother. 2017, 13, 2678-2687. [CrossRef] [PubMed]

94. Akuma, P.; Okagu, O.D.; Udenigwe, C.C. Naturally Occurring Exosome Vesicles as Potential Delivery Vehicle for Bioactive Compounds. Front. Sustain. Food Syst. 2019, 3, 23. [CrossRef]

95. Yang, M.; Wu, S.Y. The Advances and Challenges in Utilizing Exosomes for Delivering Cancer Therapeutics. Front. Pharmacol. 2018, 9, 735. [CrossRef]

96. Aspe, J.R.; Diaz Osterman, C.J.; Jutzy, J.M.S.; Deshields, S.; Whang, S.; Wall, N.R. Enhancement of Gemcitabine sensitivity in pancreatic adenocarcinoma by novel exosome-mediated delivery of the Survivin-T34A mutant. J. Extracell. Vesicles 2014, 3, 23244. [CrossRef]

97. Kamerkar, S.; LeBleu, V.S.; Sugimoto, H.; Yang, S.; Ruivo, C.F.; Melo, S.A.; Lee, J.J.; Kalluri, R. Exosomes facilitate therapeutic targeting of oncogenic KRAS in pancreatic cancer. Nature 2017, 546, 498-503. [CrossRef]

98. Tian, Y.; Li, S.; Song, J.; Ji, T.; Zhu, M.; Anderson, G.J.; Wei, J.; Nie, G. A doxorubicin delivery platform using engineered natural membrane vesicle exosomes for targeted tumor therapy. Biomaterials 2014, 35, 2383-2390. [CrossRef]

99. Melzer, C.; Rehn, V.; Yang, Y.; Bähre, H.; von der Ohe, J.; Hass, R. Taxol-Loaded MSC-Derived Exosomes Provide a Therapeutic Vehicle to Target Metastatic Breast Cancer and Other Carcinoma Cells. Cancers (Basel) 2019, 11, 798. [CrossRef]

100. Kim, M.S.; Haney, M.J.; Zhao, Y.; Mahajan, V.; Deygen, I.; Klyachko, N.L.; Inskoe, E.; Piroyan, A.; Sokolsky, M.; Okolie, O.; et al. Development of exosome-encapsulated paclitaxel to overcome MDR in cancer cells. Nanomed. Nanotechnol. Biol. Med. 2016, 12, 655-664. [CrossRef]

101. Escudier, B.; Dorval, T.; Chaput, N.; André, F.; Caby, M.-P.; Novault, S.; Flament, C.; Leboulaire, C.; Borg, C.; Amigorena, S.; et al. Vaccination of metastatic melanoma patients with autologous dendritic cell (DC) derived-exosomes: Results of thefirst phase I clinical trial. J. Transl. Med. 2005, 3, 10. [CrossRef]

102. Dai, S.; Wei, D.; Wu, Z.; Zhou, X.; Wei, X.; Huang, H.; Li, G. Phase I Clinical Trial of Autologous Ascites-derived Exosomes Combined With GM-CSF for Colorectal Cancer. Mol. Ther. 2008, 16, 782-790. [CrossRef]

103. Besse, B.; Charrier, M.; Lapierre, V.; Dansin, E.; Lantz, O.; Planchard, D.; Le Chevalier, T.; Livartoski, A.; Barlesi, F.; Laplanche, A.; et al. Dendritic cell-derived exosomes as maintenance immunotherapy after first line chemotherapy in NSCLC. Oncoimmunology 2016, 5, e1071008. [CrossRef]

104. Morse, M.A.; Garst, J.; Osada, T.; Khan, S.; Hobeika, A.; Clay, T.M.; Valente, N.; Shreeniwas, R.; Sutton, M.A.; Delcayre, A.; et al. A phase I study of dexosome immunotherapy in patients with advanced non-small cell lung cancer. J. Transl. Med. 2005, 3, 9. [CrossRef] 


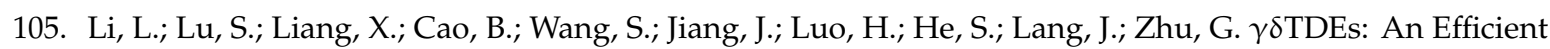
Delivery System for miR-138 with Anti-tumoral and Immunostimulatory Roles on Oral Squamous Cell Carcinoma. Mol. Ther. Nucleic Acids 2019, 14, 101-113. [CrossRef]

106. Di Bonito, P.; Accardi, L.; Galati, L.; Ferrantelli, F.; Federico, M. Anti-Cancer Vaccine for HPV-Associated Neoplasms: Focus on a Therapeutic HPV Vaccine Based on a Novel Tumor Antigen Delivery Method Using Endogenously Engineered Exosomes. Cancers (Basel) 2019, 11, 138. [CrossRef]

107. Manfredi, F.; Di Bonito, P.; Arenaccio, C.; Anticoli, S.; Federico, M. Incorporation of Heterologous Proteins in Engineered Exosomes. Methods Mol. Biol. 2016, 1448, 249-260.

108. Lattanzi, L.; Federico, M. A strategy of antigen incorporation into exosomes: Comparing cross-presentation levels of antigens delivered by engineered exosomes and by lentiviral virus-like particles. Vaccine 2012, 30, 7229-7237. [CrossRef]

109. Di Bonito, P.; Ridolfi, B.; Columba-Cabezas, S.; Giovannelli, A.; Chiozzini, C.; Manfredi, F.; Anticoli, S.; Arenaccio, C.; Federico, M. HPV-E7 delivered by engineered exosomes elicits a protective CD8 ${ }^{+} \mathrm{T}$ cell-mediated immune response. Viruses 2015, 7, 1079-1099. [CrossRef]

110. Di Bonito, P.; Chiozzini, C.; Arenaccio, C.; Anticoli, S.; Manfredi, F.; Olivetta, E.; Ferrantelli, F.; Falcone, E.; Ruggieri, A.; Federico, M. Antitumor HPV E7-specific CTL activity elicited by in vivo engineered exosomes produced through DNA inoculation. Int. J. Nanomed. 2017, 12, 4579-4591. [CrossRef]

111. Kim, D.H.; Kothandan, V.K.; Kim, H.W.; Kim, K.S.; Kim, J.Y.; Cho, H.J.; Lee, Y.-K.; Lee, D.-E.; Hwang, S.R. Noninvasive Assessment of Exosome Pharmacokinetics In Vivo: A Review. Pharmaceutics 2019, 11, 649. [CrossRef] [PubMed]

(C) 2020 by the authors. Licensee MDPI, Basel, Switzerland. This article is an open access article distributed under the terms and conditions of the Creative Commons Attribution (CC BY) license (http://creativecommons.org/licenses/by/4.0/). 